\#USCS

-

. ind

Prepared in cooperation with the Federal Emergency Management Agency

(2)

Characterization of Peak Streamflows and Flood Inundation of Selected Areas in Louisiana from the August 2016 Flood
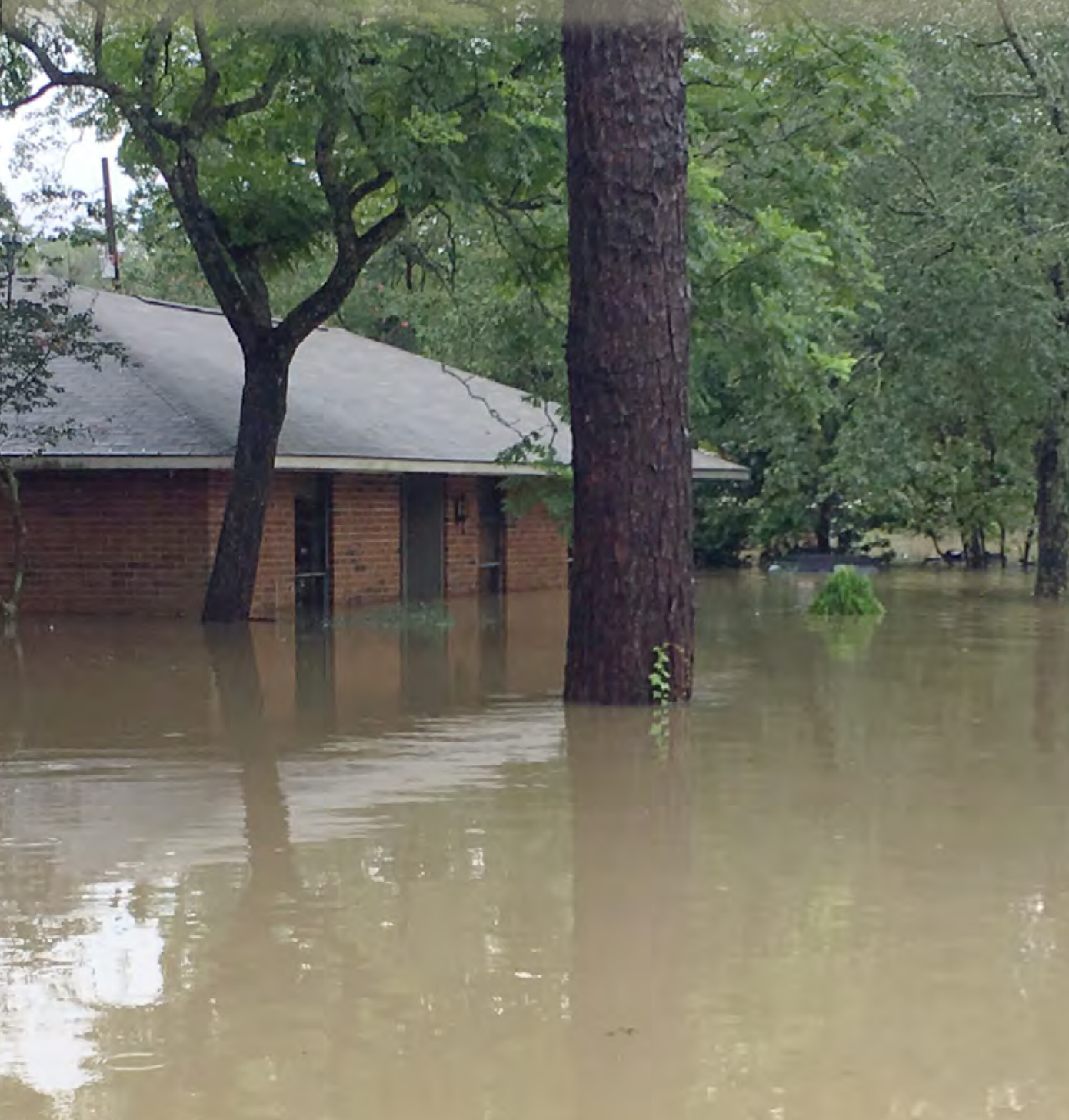

Scientific Investigations Report 2017-5005
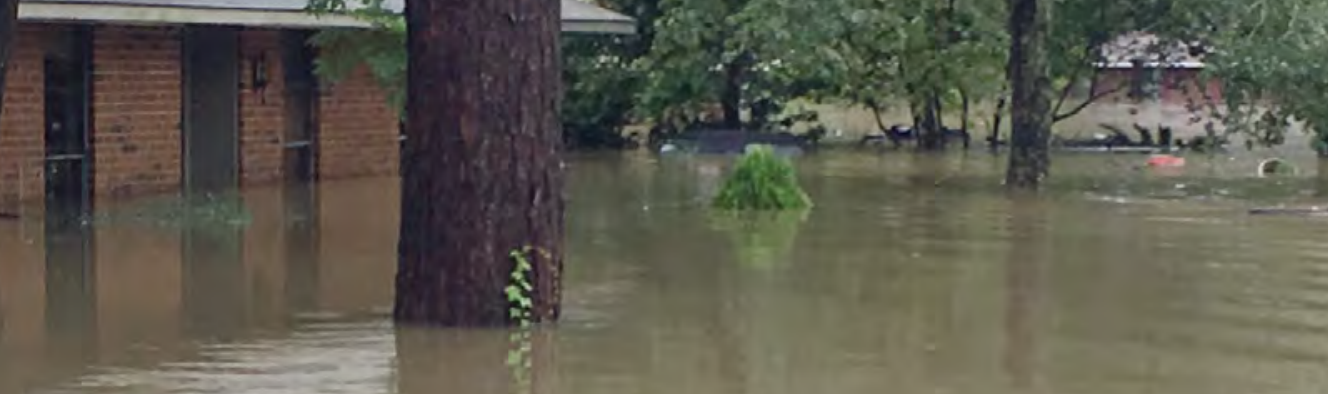

in
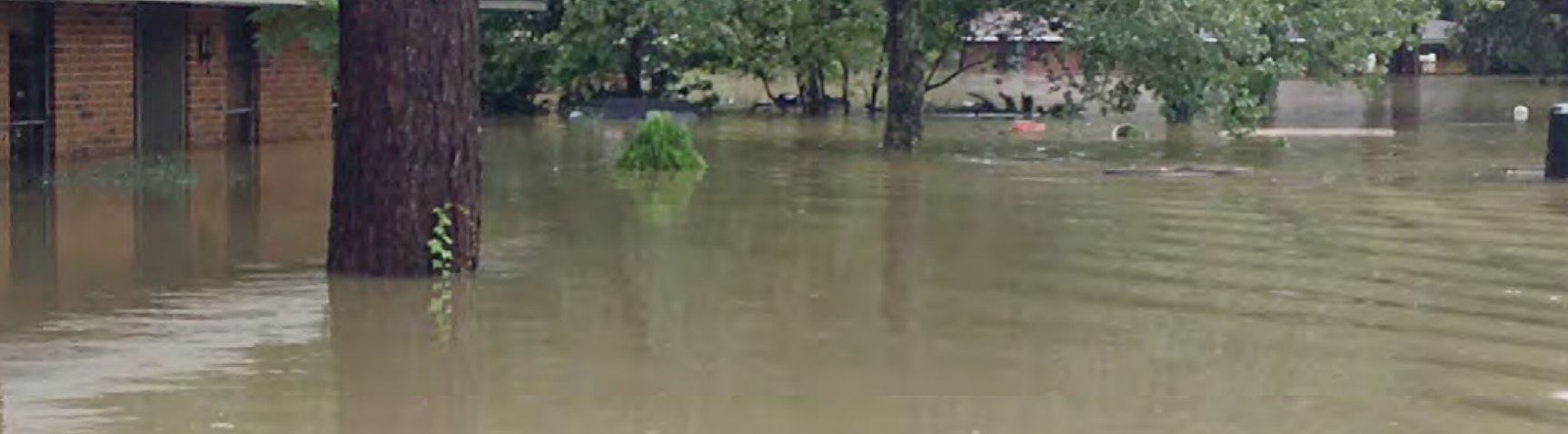
Front cover. Neighborhood west of the Amite River at the Denham Springs streamflow-gaging station, Louisiana, August 13, 2016. Photograph by James Fountain, U.S. Geological Survey.

Back cover. Flooded home near Amite River, Port Vincent, Louisiana, August 16, 2016. Photograph by James Fountain, U.S. Geological Survey.

Map showing study area and location of flood-inundation mapping extents in Louisiana for the August 2016 flood. 


\section{Characterization of Peak Streamflows and Flood Inundation of Selected Areas in Louisiana from the August 2016 Flood}

By Kara M. Watson, John B. Storm, Brian K. Breaker, and Claire E. Rose

Prepared in cooperation with the Federal Emergency Management Agency

Scientific Investigations Report 2017-5005 


\section{U.S. Department of the Interior SALLY JEWELL, Secretary}

\section{U.S. Geological Survey Suzette M. Kimball, Director}

\section{U.S. Geological Survey, Reston, Virginia: 2017}

For more information on the USGS - the Federal source for science about the Earth, its natural and living resources, natural hazards, and the environment—visit http://www.usgs.gov or call 1-888-ASK-USGS.

For an overview of USGS information products, including maps, imagery, and publications, visit http://www.usgs.gov/ pubprod/.

Any use of trade, firm, or product names is for descriptive purposes only and does not imply endorsement by the U.S. Government.

Although this information product, for the most part, is in the public domain, it also may contain copyrighted materials as noted in the text. Permission to reproduce copyrighted items must be secured from the copyright owner.

Suggested citation:

Watson, K.M., Storm, J.B., Breaker, B.K., and Rose, C.E., 2017, Characterization of peak streamflows and flood inundation of selected areas in Louisiana from the August 2016 flood: U.S. Geological Survey Scientific Investigations Report 2017-5005, 26 p., https://doi.org/10.3133/sir20175005.

ISSN 2328-0328 (online) 


\section{Contents}

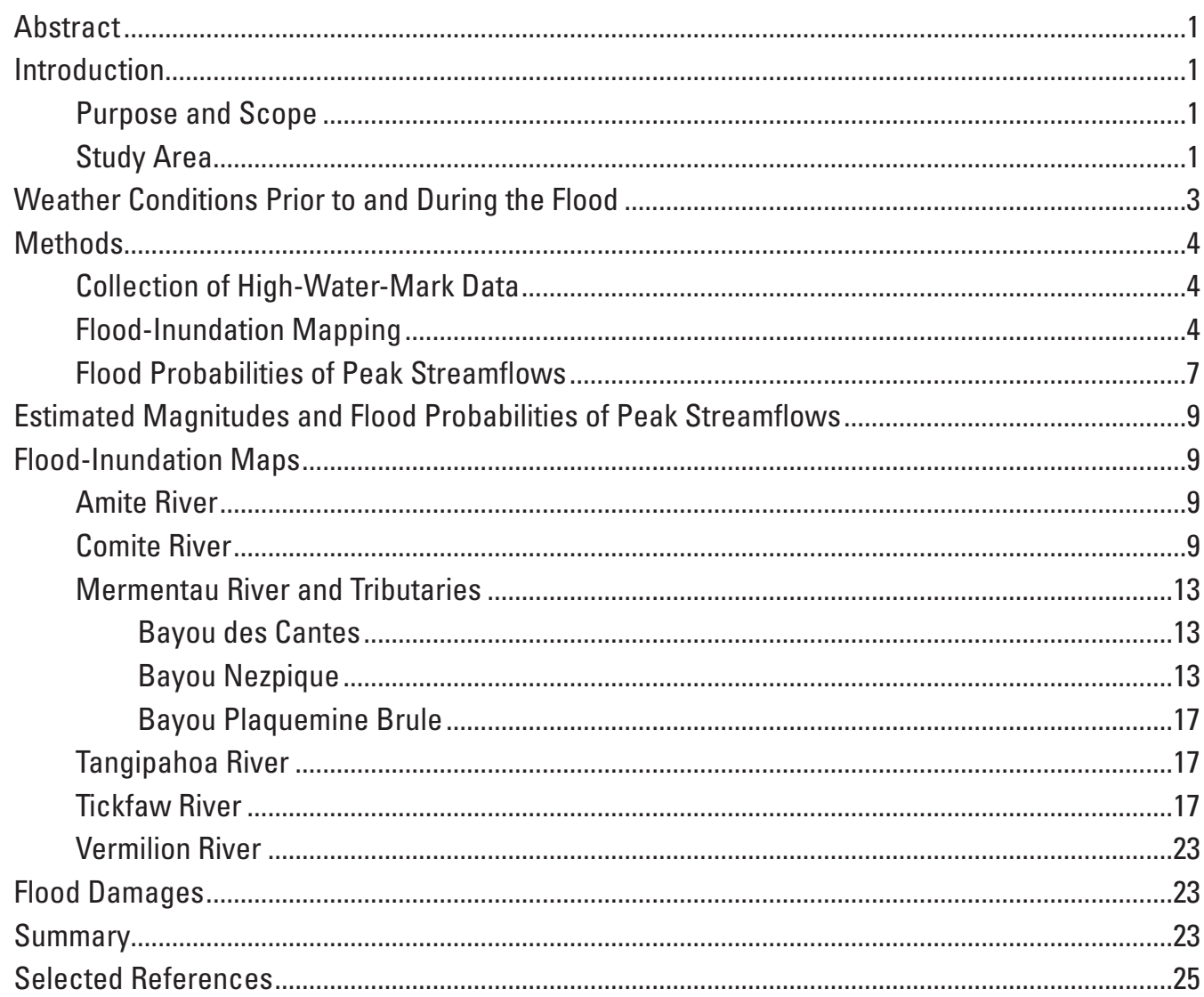

\section{Figures}

1. Map showing cumulative rainfall from August 11 to August 14, 2016, and location of U.S. Geological Survey streamflow-gaging stations used to calculate annual exceedance probabilities.............................................................2

2. Map showing study area and location of flood-inundation mapping extents in Louisiana for the August 2016 flood

3-14. Flood-innundation maps:

3. The upper reach of the Amite River, Louisiana, August 2016 ........................................10

4. The lower reach of the Amite River, Louisiana, August 2016 ......................................11

5. The upper and lower reaches of the Amite River, Louisiana, August 2016......................12

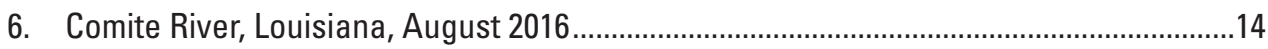

7. Mermentau River, Louisiana, August 2016 ............................................................15

8. Bayou des Cantes, tributary to Mermentau River, Louisiana, August 2016 _....................16

9. Bayou Nezpique, tributary to Mermentau River, Louisiana, August 2016 .........................18

10. Bayou Plaquemine Brule, tributary to Mermentau River, Louisiana, August 201 ............19

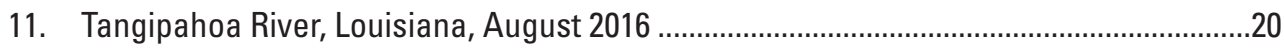

12. The upper reach of Tickfaw River, Louisiana, August 2016 ...........................................21

13. Area around the mouth of Tickfaw River, Louisiana, August 2016 .................................22

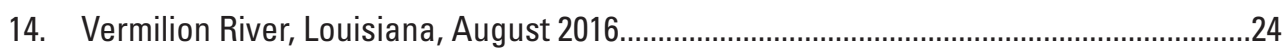




\section{Tables}

1. Site identification number, station information, peak information, location, and drainage area of U.S. Geological Survey streamflow-gaging stations.

2. Rainfall totals reported from National Oceanic and Atmospheric Administration meteorological stations during August 11-14, 2016, floods in Louisiana.

3. Flood-peak gage heights and peak streamflows for the March and August 2016 floods and previous peak streamflows at selected U.S. Geological Survey streamflow-gaging stations in Louisiana.

4. Communities, waterbodies, reach lengths, and number of high-water marks used to generate flood-inundation maps.

5. Site identification number, station number, peak information, and estimated annual exceedance probabilities for selected U.S. Geological

Survey streamflow-gaging stations in Louisiana.

\section{Conversion Factors}

U.S. customary units to International System of Units

\begin{tabular}{|c|c|c|}
\hline Multiply & By & To obtain \\
\hline \multicolumn{3}{|c|}{ Length } \\
\hline inch (in.) & 2.54 & centimeter $(\mathrm{cm})$ \\
\hline inch (in.) & 25.4 & millimeter $(\mathrm{mm})$ \\
\hline foot $(\mathrm{ft})$ & 0.3048 & meter $(\mathrm{m})$ \\
\hline mile (mi) & 1.609 & kilometer $(\mathrm{km})$ \\
\hline \multicolumn{3}{|c|}{ Area } \\
\hline square mile $\left(\mathrm{mi}^{2}\right)$ & 259.0 & hectare (ha) \\
\hline square mile $\left(\mathrm{mi}^{2}\right)$ & 2.590 & square kilometer $\left(\mathrm{km}^{2}\right)$ \\
\hline \multicolumn{3}{|c|}{ Flow rate } \\
\hline cubic foot per second $\left(\mathrm{ft}^{3} / \mathrm{s}\right)$ & 0.02832 & cubic meter per second $\left(\mathrm{m}^{3} / \mathrm{s}\right)$ \\
\hline
\end{tabular}

International System of Units to U.S. customary units

\begin{tabular}{lll}
\hline \multicolumn{1}{c}{ Multiply } & By & \multicolumn{1}{c}{ To obtain } \\
\hline & Length & \\
\hline centimeter $(\mathrm{cm})$ & 0.3937 & inch (in.) \\
meter (m) & 3.281 & foot (ft) \\
meter (m) & 1.094 & yard (yd) \\
\hline
\end{tabular}




\section{Datum}

Vertical coordinate information is referenced to the North American Vertical Datum of 1988

(NAVD 88) and National Geodetic Vertical Datum of 1929 (NGVD 29)

Horizontal coordinate information is referenced to the North American Datum of 1983 (NAD 83).

Elevation, as used in this report, refers to distance above the vertical datum.

\section{Abbreviations}

AEP annual exceedance probability

DEM digital elevation model

FEMA Federal Emergency Management Agency

GIS geographic information system

GPS Global Positioning System

HWM high-water mark

lidar light detection and ranging

NOAA National Oceanic and Atmospheric Administration

USGS U.S. Geological Survey 



\title{
Characterization of Peak Streamflows and Flood Inundation of Selected Areas in Louisiana from the August 2016 Flood
}

\author{
By Kara M. Watson, John B. Storm, Brian K. Breaker, and Claire E. Rose
}

\begin{abstract}
Heavy rainfall occurred across Louisiana and southwestern Mississippi in August 2016 as a result of a slow-moving area of low pressure and a high amount of atmospheric moisture. The storm caused major flooding in the southern portions of Louisiana including areas surrounding Baton Rouge and Lafayette. Flooding occurred along the rivers such as the Amite, Comite, Tangipahoa, Tickfaw, Vermilion, and Mermentau Rivers. Over 31 inches of rain was reported in the city of Watson, 20 miles northeast of Baton Rouge, La., over the duration of the event. Streamflow-gaging stations operated by the U.S. Geological Survey (USGS) recorded peak streamflows of record at 10 locations, and 7 other locations experienced peak streamflows ranking in the top five for the duration of the period of record. In August 2016, USGS hydrographers made 50 discharge measurements at 21 locations on streams in Louisiana. Many of those discharge measurements were made for the purpose of verifying the accuracy of stage-streamflow relations at gaging stations operated by the USGS. Following the storm event, USGS hydrographers recovered and documented 590 highwater marks, noting location and height of the water above land surface. Many of these high-water marks were used to create 12 flood-inundation maps for selected communities of Louisiana that experienced flooding in August 2016. Digital datasets of the inundation area, modeling boundary, water depth rasters, and final map products are available online.
\end{abstract}

\section{Introduction}

A slow-moving sheared inland tropical depression gained energy and moisture as it moved from the Southeast across the gulf coast to Louisiana and southwestern Mississippi during the period of August 9-14, 2016. The majority of the rain fell in Louisiana from August 11 to 14 and caused major flooding across southern Louisiana, with rainfall amounts exceeding 31 inches (in.) in some areas (National Oceanic and Atmospheric Administration, 2016; fig.1).
Historic flooding occurred in areas of Louisiana as a result of the prolonged, heavy rainfall. Damages resulting from flooding were estimated to be $\$ 10$ billion (National Oceanic and Atmospheric Administration, 2016a) and resulted in at least 13 fatalities (National Oceanic and Atmospheric Administration, 2016b). In the immediate aftermath of the August 2016 flood, the U.S. Geological Survey (USGS) and the Federal Emergency Management Agency (FEMA) initiated a cooperative study to evaluate the flood's magnitude, extent, and probability of occurrence. Flood-peak streamflow data were recorded for 16 streamflow-gaging stations operated by the USGS in Louisiana (table 1, fig. 1).

\section{Purpose and Scope}

The purpose of this report is to document the data collection, flood-peak magnitudes, and flood-inundation products generated by the USGS in support of the FEMA response and recovery operations following the August 2016 flood event in Louisiana. The technical scope of the report includes (1) description of the atmospheric conditions and the temporal and spatial patterns of rainfall that triggered the flooding and a narrative of the flood and its effects, (2) analysis of peak-flow magnitudes and the statistical probabilities at selected locations, and (3) the identification and surveying of high-water marks (HWM) and the geographic information system (GIS) analysis of HWM locations and elevations to produce flood-inundation maps (areal extent and depth of flooding) for six heavily flooded areas in Louisiana.

\section{Study Area}

The geographic scope of the report encompasses most of southern Louisiana. Areas affected by flooding described within this report lie within the West Gulf Coastal Plain, Mississippi Alluvial Plain, and East Gulf Coastal Plain physiographic sections (Fenneman, 1946; fig. 1). In general, the area consists of rolling hills in the northern parts of the study area and flat lands with swamps and marshes in the 


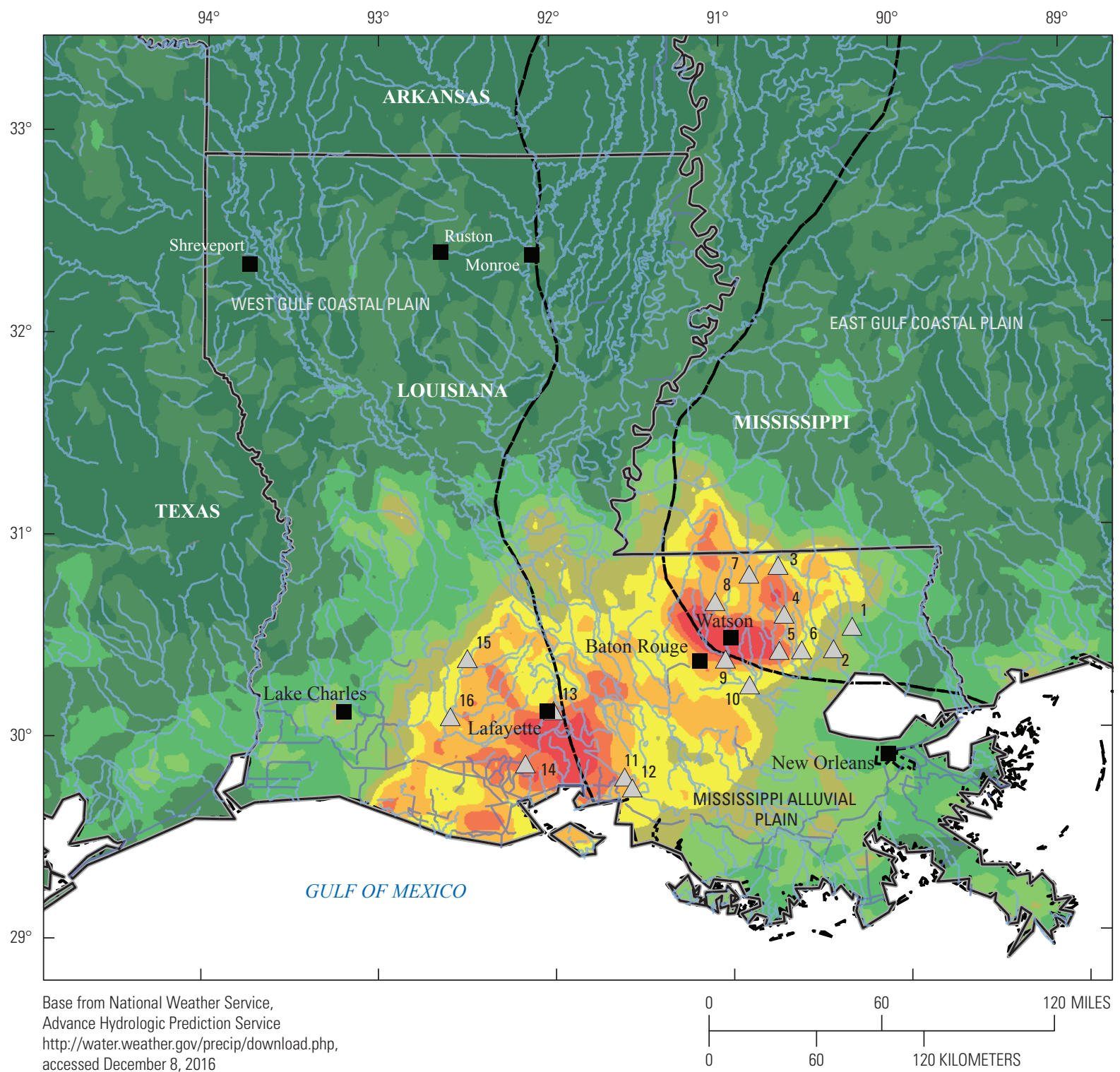

accessed December 8, 2016

EXPLANATION

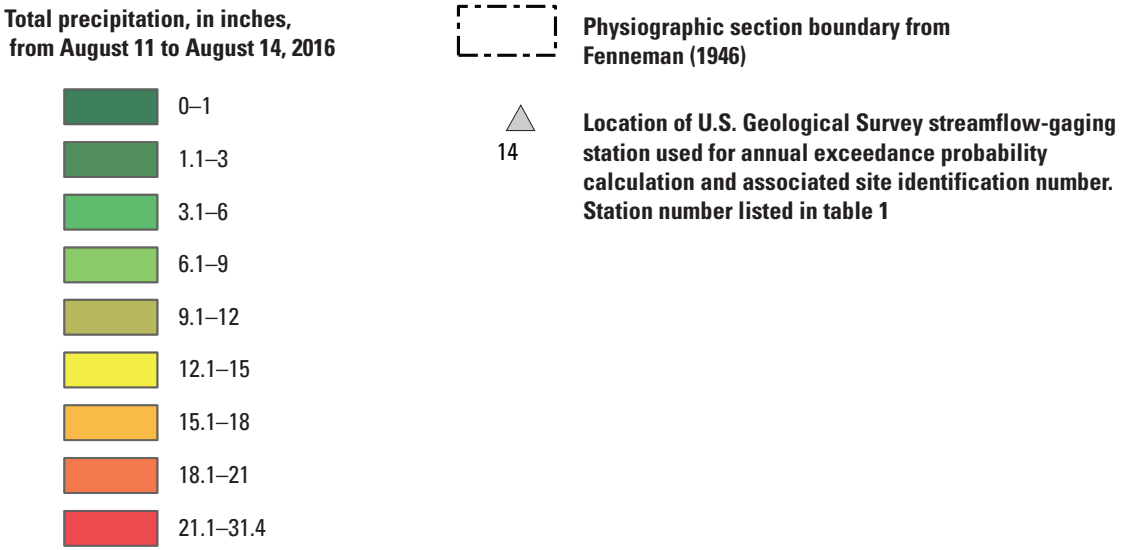

Figure 1. Cumulative rainfall from August 11 to August 14, 2016, and location of U.S. Geological Survey streamflowgaging stations used to calculate annual exceedance probabilities. 
Table 1. Site identification number, station information, peak information, location, and drainage area of U.S. Geological Survey streamflow-gaging stations.

[mi², square miles; LA, Louisiana; --, no data]

\begin{tabular}{crlccc}
\hline $\begin{array}{c}\text { Site iden- } \\
\text { tification } \\
\text { number } \\
\text { (fig. 1) }\end{array}$ & $\begin{array}{c}\text { Station } \\
\text { number }\end{array}$ & \multicolumn{1}{c}{ Station name } & $\begin{array}{c}\text { Drainage } \\
\text { area } \\
\text { (mí) }\end{array}$ & $\begin{array}{c}\text { Latitude } \\
\text { (decimal } \\
\text { degrees) }\end{array}$ & $\begin{array}{c}\text { Longitude } \\
\text { (decimal } \\
\text { degrees) }\end{array}$ \\
\hline 1 & 07375000 & Tchefuncta River near Folsom, LA & 103 & 30.61602 & -90.24870 \\
2 & 07375500 & Tangipahoa River at Robert, LA & 646 & 30.50658 & -90.36175 \\
3 & 07375800 & Tickfaw River at Liverpool, LA & 89.7 & 30.93074 & -90.67343 \\
4 & 07375960 & Tickfaw River at Montpelier, LA & 220 & 30.68630 & -90.64315 \\
5 & 07376000 & Tickfaw River at Holden, LA & 247 & 30.50380 & -90.67732 \\
6 & 07376500 & Natalbany River at Baptist, LA & 79.5 & 30.50436 & -90.54592 \\
7 & 07377000 & Amite River near Darlington, LA & 580 & 30.88907 & -90.84455 \\
8 & 07377500 & Comite River near Olive Branch, LA & 145 & 30.75657 & -91.04399 \\
9 & 07378500 & Amite River near Denham Springs, LA & 1,280 & 30.46408 & -90.99038 \\
10 & 07380120 & Amite River at Port Vincent, LA & 1,596 & 30.33269 & -90.85204 \\
11 & 07385765 & Bayou Teche at Adeline Bridge near Jeanerette, LA & - & 29.87937 & -91.58622 \\
12 & 07385790 & Charenton Drainage and Navigation Canal at Baldwin, LA & -- & 29.82306 & -91.54167 \\
13 & 07386880 & Vermilion River at Surrey Street at Lafayette, LA & -- & 30.21742 & -91.99290 \\
14 & 07386980 & Vermilion River at Perry, LA & -- & 29.95111 & -92.15636 \\
15 & 08010000 & Bayou Des Cannes near Eunice, LA & 131 & 30.48289 & -92.49069 \\
16 & 08012150 & Mermentau River At Mermentau, LA & 1,381 & 30.19000 & -92.59056 \\
\hline
\end{tabular}

southern parts of the study area. Land-surface elevations within the affected areas range in elevation from about -1 to about 400 feet (ft) relative to the North American Vertical Datum of 1988 (NAVD 88). The 30-year normal rainfall from 1981 to 2010 in Louisiana varies from 49 in. in northwestern Louisiana to 68 in. in southern Louisiana (Durre and others, 2012).

\section{Weather Conditions Prior to and During the Flood}

Heavy rainfall occurred across Louisiana and southwestern Mississippi during August 11-14, 2016, as a result of a slow-moving sheared inland tropical depression, which gained energy and moisture as it moved as a low pressure system across the gulf coast into Louisiana and southern Mississippi. The system tapped into deep tropical moisture resulting in intense rainfall and thunderstorms across a large part of the area causing major flooding across southern Louisiana.

The NOAA rainfall data showed the heaviest rainfall occurred across a swath of East Baton Rouge, Livingston, and St. Helena Parishes, where 20 to more than 31 in. fell over a 48-hour period, topping the 0.2-percent annual exceedance probability (AEP) (National Oceanic and Atmospheric Administration, 2016c). The city of Watson, La., received 31.39 in. of rain during August 11-14, and the town of Livingston recorded $17 \mathrm{in}$. of rain in a single day (National Oceanic and Atmospheric Administration, 2016d). Two-day rainfall totals of $20 \mathrm{in}$. or more were common across areas around Baton Rouge and Lafayette. Table 2 lists rainfall totals for the flood event for selected NOAA precipitation stations across southern Louisiana.

The heavy rainfall led to widespread flash flooding and record river flooding. Many of the broken records had been previously set during the flooding of April 1983. In total, 13 people died in southern Louisiana as a result of the flooding. The event was also responsible for an estimated total of $\$ 10$ billion in damages across southern Louisiana and southwestern Mississippi (National Oceanic and Atmospheric Administration, 2016a). This estimate includes impacts of the initial flash flooding and the resultant river flooding. August 2016 was the wettest month on record for Louisiana with a statewide average of 12.9 in., topping the previous record of 9.71 in. set in August 1940 (National Oceanic and Atmospheric Administration, 2016d).

Some of the same communities and rivers in Louisiana that flooded in August also flooded in March 2016 from heavy rainfall that occurred across Louisiana, Texas, Arkansas, and Mississippi (Breaker and others, 2016). The areas around 
Table 2. Rainfall totals reported from National Oceanic and Atmospheric Administration meteorological stations during August 11-14, 2016, floods in Louisiana. (From National Oceanic and Atmospheric Administration Climatological Data, 2016e)

[NE, northeast; LSU, Louisiana State University; SW, southwest; FCWOS, FAA contract weather observing station; AP, Airport]

\begin{tabular}{lc}
\hline \multicolumn{1}{c}{ Location } & $\begin{array}{c}\text { Rainfall } \\
\text { amounts } \\
\text { (inches) }\end{array}$ \\
\hline New Roads 5 NE, Pointe Coupee Parish, Louisiana & 16.07 \\
Opelousas, St. Landry Parish, Louisiana & 15.83 \\
Baton Rouge Metro Airport, East Baton Rouge, & 18.07 \\
$\quad$ Louisiana & \\
Livingston, Livingston Parish, Louisiana & 26.33 \\
LSU Ben-Hur Farm, Baton Rouge, East Baton Rouge & 13.07 \\
$\quad$ Parish, Louisiana & \\
Norwood, East Feliciana Parish, Louisiana & 23.02 \\
Pine Grove Fire Tower (7 miles west of Montpelier), & 17.55 \\
$\quad$ St. Helena Parish, Louisiana & \\
Ponchatoula, Tangipahoa Parish, Louisiana & 8.61 \\
St. Francisville, West Feliciana Parish, Louisiana & 19.38 \\
Abbeville, Vermilion Parish, Louisiana & 19.05 \\
Crowley 2 NE, Acadia Parish, Louisiana & 16.96 \\
Jennings, Jefferson Davis Parish, Louisiana & 16.94 \\
Kaplan, Vermilion Parish, Louisiana & 15.23 \\
Lake Arthur 7 SW, Jefferson Davis Parish, Louisiana & 15.59 \\
Donaldsonville 4 SW, Ascension Parish, Louisiana & 15.59 \\
Lafayette FCWOS, Lafayette Parish, Louisiana & 21.35 \\
New Iberia AP-Acadiana Regional, Iberia Parish, & 23.03 \\
$\quad$ Louisiana & \\
Jeanerette 5 NW, Iberia Parish, Louisiana & 25.1 \\
Dutchtown \#2, Ascension Parish, Louisiana & 17.88 \\
Gonzales, Ascension Parish, Louisiana & 16.9 \\
\hline & 14.54 \\
\hline
\end{tabular}

the Amite River, Tangipahoa River, and Tickfaw River, in particular, experienced high peak streamflow from both events. A comparison of the peak streamflow data from the August and March 2016 floods is shown in table 3.

\section{Methods}

The methods by which HWMs resulting from flooding were identified, documented, and referenced as well as the methods used to create flood-inundation maps using these HWMs are discussed in this section. The estimation of flood magnitude and frequency were developed through analysis of the annual peak streamflows at 16 streamflow-gaging stations (table 1) operated by the USGS, and these methods are also discussed in this section. All streamflow data used in support of this report can be accessed from the USGS National Water Information System (U.S. Geological Survey, 2017).

\section{Collection of High-Water-Mark Data}

High-water marks provide valuable data for understanding flood events (Koenig and others, 2016). The best HWMs are formed from small seeds or floating debris carried by floodwaters that adhere to smooth surfaces or lodge in tree bark to form a distinct line. Stain lines on buildings, fences, and other structures also provide excellent marks. The HWMs are best identified immediately following the peak stage because time and weather may alter evidence of the peak water line. The HWMs collected for this flood event were made available through the USGS Short-Term Network (STN; U.S. Geological Survey, 2016), which is an online interface created to facilitate the dissemination of field data.

The USGS field crews identified 590 HWMs in Louisiana with a depth above land-surface measurement made in feet and 465 of these HWMs were surveyed for elevation above land surface. Identification and marking of HWMs began on August 23 and continued through September 10, 2016. After an acceptable HWM was identified, a more permanent identification mark was established, such as a Parker-Kalon nail with a disk, a stake, a chiseled mark, or a paint line. Written descriptions, sketches, photographs, and Global Positioning System (GPS) horizontal measurements obtained with a hand-held GPS unit were made so the marks could easily be found later and surveyed to the standard vertical datum, NAVD 88.

During the mapping process, the HWMs used to create flood-inundation maps (Heal and Watson, 2017) were checked for location and elevation accuracy through comparison of field note diagrams and descriptions to aerial photography and detailed street and parcel maps. The HWM was not used if the location could not be determined accurately or the elevation was substantially different from other HWMs in the area.

\section{Flood-Inundation Mapping}

Twelve flood-inundation maps were created along impacted rivers using GIS for several communities in southern Louisiana (fig. 2). Flood-inundation maps are intended to estimate the aerial extent and depth of flooding that correspond to the HWMs identified and surveyed by USGS hydrographers following the flood event. Table 4 lists the community, parish, waterbody, reach length, and number of HWMs used to generate the flood-inundation maps. The first step in the generation of the flood-inundation maps was the creation of a flood-elevation raster surface. Flood extent and depth surfaces were created independently for each community using the HWM elevations and a GIS interpolation technique. A geographic limit was placed on the extent of the 
Table 3. Flood-peak gage heights and peak streamflows for the March and August 2016 floods and previous peak streamflows at selected U.S. Geological Survey streamflow-gaging stations in Louisiana.

[Data shown are considered provisional as of the date of publication. Peak of record shown in bold. $\mathrm{ft}$, feet; $\mathrm{ft}^{3} / \mathrm{s}$, cubic feet per second; <, less than; NA, annual exceedance probability not computed; --, no data]

\begin{tabular}{|c|c|c|c|c|c|}
\hline \multirow[b]{2}{*}{$\begin{array}{l}\text { Station } \\
\text { number }\end{array}$} & \multicolumn{5}{|c|}{ Maximum streamflow for August 2016 flood } \\
\hline & Date & $\begin{array}{c}\text { Peak gage } \\
\text { height } \\
\text { (ft) }\end{array}$ & $\begin{array}{c}\text { Peak } \\
\text { streamflow } \\
\left(\mathrm{ft}^{3} / \mathrm{s}\right)\end{array}$ & $\begin{array}{c}\text { Estimated annual } \\
\text { exceedance probability } \\
\text { (percent) }\end{array}$ & $\begin{array}{c}\text { Rank/number of annual } \\
\text { peak streamflows } \\
\text { in record }\end{array}$ \\
\hline 07375000 & $8 / 13 / 2016$ & 24.28 & 32,700 & 1 & $2 / 73$ \\
\hline 07375500 & $8 / 13 / 2016$ & 27.33 & 120,000 & $<0.2$ & $1 / 78$ \\
\hline 07375800 & $8 / 12 / 2016$ & 13.87 & 43,000 & 0.9 & $1 / 60$ \\
\hline 07376000 & $8 / 13 / 2016$ & 22.16 & 35,800 & $<0.2$ & $1 / 76$ \\
\hline 07376500 & $8 / 12 / 2016$ & 25.58 & 22,100 & $<0.2$ & $1 / 73$ \\
\hline 07377000 & $8 / 12 / 2016$ & 22.54 & 116,000 & 1 & $1 / 68$ \\
\hline 07377500 & $8 / 13 / 2016$ & 27.28 & 78,000 & $<0.2$ & $1 / 74$ \\
\hline 07378500 & $8 / 14 / 2016$ & 46.2 & 205,000 & $<0.2$ & $1 / 78$ \\
\hline 07386880 & $8 / 15 / 2016$ & 17.62 & $\begin{array}{c}5,260 \\
(2016-08-21)\end{array}$ & 5 & $3 / 48$ \\
\hline 07386980 & $8 / 14 / 2016$ & 13.75 & 15,400 & 4.4 & $2 / 31$ \\
\hline 08010000 & $8 / 16 / 2016$ & 22.37 & $\begin{array}{c}11,500 \\
(2016-08-14)\end{array}$ & $1-2$ & $2 / 77$ \\
\hline 08012150 & $8 / 18 / 2016$ & 10.82 & 40,500 & NA & $4 / 72$ \\
\hline
\end{tabular}

\begin{tabular}{|c|c|c|c|c|c|c|}
\hline \multirow[b]{2}{*}{$\begin{array}{l}\text { Station } \\
\text { number }\end{array}$} & \multicolumn{3}{|c|}{ Maximum streamflow for March 2016 flood } & \multicolumn{3}{|c|}{ Previous maximum streamflow } \\
\hline & Date & $\begin{array}{c}\text { Peak } \\
\text { gage height } \\
\text { (ft) }\end{array}$ & $\begin{array}{c}\text { Peak } \\
\text { streamflow } \\
\left(\mathrm{ft}^{3} / \mathbf{s}\right)\end{array}$ & Date & $\begin{array}{l}\text { Peak gage } \\
\text { height } \\
\text { (ft) }\end{array}$ & $\begin{array}{c}\text { Peak } \\
\text { streamflow } \\
\left(\mathbf{f t}^{3} / \mathbf{s}\right)\end{array}$ \\
\hline 07375000 & 3/11/2016 & 25.25 & 43,000 & $4 / 6 / 1983$ & 24.12 & 29,800 \\
\hline 07375500 & $3 / 12 / 2016$ & 25.52 & 85,300 & $4 / 7 / 1983$ & 25.87 & 85,000 \\
\hline 07375800 & $3 / 11 / 2016$ & 12.47 & 16,800 & $4 / 6 / 1983$ & 13.3 & 32,000 \\
\hline 07375960 & $3 / 11 / 2016$ & 18.72 & 21,500 & $5 / 23 / 1974$ & 108.311 & 28,400 \\
\hline 07376000 & $3 / 11 / 2016$ & 20.23 & 16,700 & 4/7/1983 & 21.04 & 22,500 \\
\hline 07376500 & $3 / 11 / 2016$ & 19.76 & 8,190 & $4 / 7 / 1983$ & 20.8 & 9,810 \\
\hline 07377000 & $3 / 12 / 2016$ & 16.82 & 36,400 & $1 / 25 / 1990$ & 22.05 & 104,000 \\
\hline 07377500 & $3 / 11 / 2016$ & 14.00 & 11,100 & $6 / 8 / 2001$ & 19.15 & 25,300 \\
\hline 07378500 & $3 / 13 / 2016$ & 36.09 & 65,200 & $4 / 8 / 1983$ & 41.5 & 112,000 \\
\hline 07380120 & $3 / 14 / 2016$ & 11.20 & 41,700 & $1 / 28 / 1990$ & -- & 69,500 \\
\hline 07385765 & $3 / 10 / 2016$ & -- & 1,400 & $7 / 6 / 2010$ & 4.69 & 4,750 \\
\hline 07385790 & $3 / 11 / 2016$ & 3.54 & $\begin{array}{c}13,600 \\
(3 / 19 / 2016)\end{array}$ & $1 / 16 / 2013$ & 2.04 & 20,600 \\
\hline 07386880 & $3 / 12 / 2016$ & 11.58 & $\begin{array}{c}2790 \\
(3 / 20 / 2016)\end{array}$ & 7/17/1989 & -- & 6,280 \\
\hline 07386980 & $3 / 12 / 2016$ & 8.83 & 7,520 & $10 / 28 / 1985$ & -- & 15,800 \\
\hline 08010000 & $3 / 13 / 2016$ & 16.73 & 2,710 & $5 / 20 / 1953$ & 22.36 & 11,900 \\
\hline 08012150 & $3 / 15 / 2016$ & 3.89 & 12,100 & $11 / 2 / 1985$ & -- & 58,000 \\
\hline
\end{tabular}




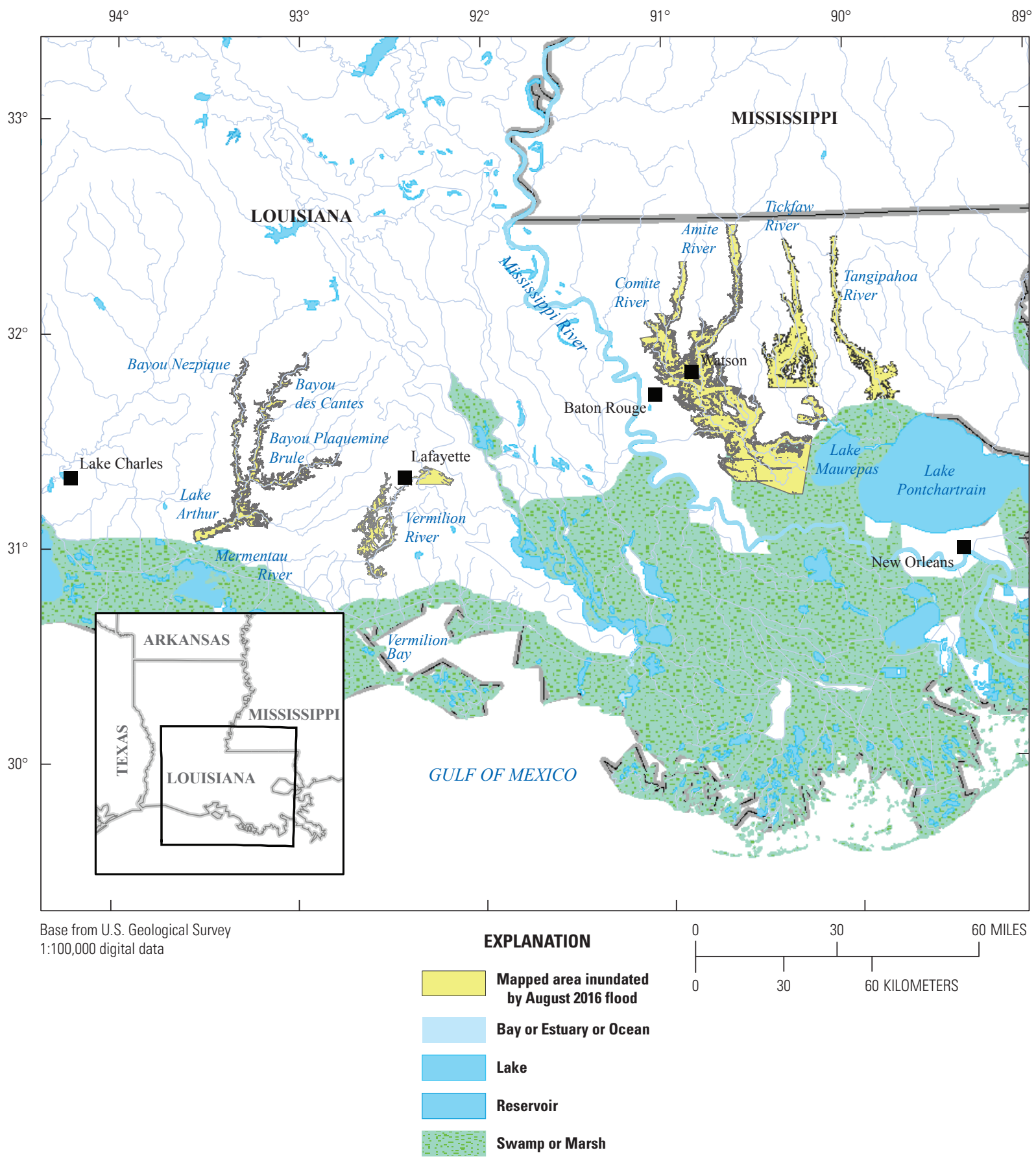

Figure 2. Study area and location of flood-inundation mapping extents in Louisiana for the August 2016 flood. 
Table 4. Communities, waterbodies, reach lengths, and number of high-water marks used to generate flood-inundation maps.

\begin{tabular}{|c|c|c|c|c|}
\hline Community & Parish & Waterbody & $\begin{array}{l}\text { Reach } \\
\text { length } \\
\text { (miles) }\end{array}$ & $\begin{array}{c}\text { Number } \\
\text { of high- } \\
\text { water } \\
\text { marks }\end{array}$ \\
\hline $\begin{array}{l}\text { Denham Springs, Port Vincent, } \\
\text { French Settlement, Maurepas }\end{array}$ & $\begin{array}{l}\text { East Feliciana, St. Helena, East Baton Rouge, } \\
\text { Livingston, Ascension, St. James, St. John the } \\
\text { Baptist }\end{array}$ & Amite River & 68 & 167 \\
\hline $\begin{array}{l}\text { Baton Rouge, North Baton } \\
\text { Rouge }\end{array}$ & East Baton Rouge, East Feliciana & Comite River & 33 & 35 \\
\hline Mermentau & Jefferson Davis, Acadia, Cameron, Vermilion & Mermentau River & 16.3 & 12 \\
\hline Eunice, Mermentau & Jefferson Davis, Acadia, Evangeline, St. Landry & Bayou des Cantes & 38 & 9 \\
\hline Basile, Mermentau & Jefferson Davis, Acadia, Allen, Evangeline & Bayou Nezpique & 33 & 11 \\
\hline Crowley, Estherwood & Jefferson Davis, Acadia & Bayou Plaquemine Brule & 26 & 6 \\
\hline $\begin{array}{l}\text { Kentwood, East Ponchatoula, } \\
\text { Hammond }\end{array}$ & Tangipahoa & Tangipahoa River & 40 & 20 \\
\hline Liverpool, Montpelier, Holden & St. Helena, Livingston & Tickfaw River- upper/middle & 33 & 58 \\
\hline Killian & Livingston & Tickfaw River- near mouth & 7 & 9 \\
\hline Lafayette, Abbeville, Perry & St. Martin, Lafayette, Vermilion & Vermilion River & 34 & 36 \\
\hline
\end{tabular}

generated surface based on the distribution of HWMs and an understanding of the natural hydrologic flow in the area of each community. The GIS interpolation method used to create the flood-inundation maps follows those described for the "Topo to Raster" tool in Musser and others (2016).

The flood-elevation surface that was created by using GIS interpolation was then combined with a 5-meter cell size digital elevation model (DEM). The DEM was derived from light detection and ranging (lidar) data having a 15-30-centimeter vertical root-mean-square error and will support contours of 1-2 ft vertical map accuracy standards (Louisiana State University, 2016). An inundated area was depicted where the flood-elevation surface was higher than the DEM land surface. The depth of flooding was determined as the difference between the flood-elevation surface and the DEM land surface. Because of the large number of bridges involved in the flood-inundation mapping, the inundation surfaces were not clipped to show bridges that were not inundated.

Uncertainties in the mapped extent and depth of flooding exist within the maps because of the mapping methods used and the number and spatial distribution of HWMs. Hydraulic models were not used to determine the extent or depth of flood inundation. The flood-elevation surfaces were all created using interpolation between HWM elevations rather than hydraulic models. Changes in land-surface features in flood plains, timing of the flooding that may occur from some of the smaller inflow tributaries versus the larger main stem tributaries, and the intermingling flows from adjacent streams are not accounted for without hydraulic models. In locations where HWMs are spaced farther apart, there is a greater possibility of decreased accuracy of spatial interpretation of the extent and depth of flood inundation. Within a given mapped area, some extrapolation was performed beyond the most upstream and downstream HWMs. In many cases, the boundary was extended to some anthropogenic structure, such as a road or bridge crossing.

\section{Flood Probabilities of Peak Streamflows}

The probability that a peak streamflow will occur at a given location in a given year is known as the annual exceedance probability (AEP) and is determined from the existing annual peak streamflow data at a streamflowgaging station. An annual peak streamflow is the maximum instantaneous streamflow experienced at a streamflow-gaging station during a given water year (defined as October 1 through September 30 of a given year). Streamflow-gaging stations with the longest annual peak streamflow record are the most reliable for estimating an AEP. An AEP of 0.01 means there is a 1-percent chance that a specific peak streamflow may occur at a given location in a given year. The recurrence interval for a given AEP is determined by dividing 1 by the AEP; therefore, an AEP of 0.01 is equivalent to a 100-year flood.

During the month of August 2016, USGS hydrographers made over 50 streamflow measurements by using direct methods (Rantz and others, 1982a; Turnipseed and Sauer, 2010) and 8 measurements by indirect methods (Benson and Dalrymple, 1967; Rantz and others, 1982b) at 21 continuousrecord streamflow-gaging station locations. Streamflow measurements were made to verify accuracies of stagestreamflow rating curves or to extend the stage-streamflow 
rating curve for a given streamflow-gaging station (Rantz and others, 1982a). The stage-streamflow rating curve for a given streamflow-gaging station is used to calculate instantaneous streamflow values for a given streamflow-gaging station, which in turn are used to populate USGS annual peak streamflow files.

For selected streamflow-gaging stations (table 1), AEPs corresponding to peak streamflows that occurred during the August 2016 flood and streamflows associated with selected AEPs $(0.01,0.005$, and 0.002$)$ were estimated using the Expected Moments Algorithm (Cohn and others, 1997, 2001) in the USGS PeakFQ program (Veilleux and others, 2014). Outputs from the USGS PeakFQ program provide estimates for 15 specific AEPs ranging from 0.995 to 0.002 . In order to estimate AEPs for specific peak streamflows that occurred during the August 2016 floods, the 15 specific AEPs and associated streamflows produced by PeakFQ were used to create generalized additive models (GAM) with integrated smoothness estimation (Wood, 2004, 2011) in R statistical software (R Core Team, 2016). The GAMs were then used to estimate the AEP associated with the peak streamflow from the August 2016 flood. For these streamflow-gaging stations in Louisiana, AEP estimates were not weighted with regional regression equations owing to the availability of recent equations. Peak gage-height data and peak streamflow data from the August 2016 flood and the corresponding AEPs (in percentage) were determined for nine streamflow-gaging stations (fig. 1; table 5).

Table 5. Site identification number, station number, peak information, and estimated annual exceedance probabilities for selected U.S. Geological Survey streamflow-gaging stations in Louisiana.

$\left[\mathrm{ft}^{3} / \mathrm{s}\right.$, cubic feet per second; AEP, annual exceedance probability; $<$, less than]

\begin{tabular}{|c|c|c|c|c|c|c|c|c|c|c|}
\hline \multirow{3}{*}{$\begin{array}{l}\text { Site identifi- } \\
\text { cation number } \\
\text { (fig. 1) }\end{array}$} & \multirow[b]{3}{*}{$\begin{array}{l}\text { Station } \\
\text { number }\end{array}$} & \multirow{2}{*}{\multicolumn{4}{|c|}{ Flood data }} & \multicolumn{5}{|c|}{ AEP for observed August 2016 flood } \\
\hline & & & & & & \multirow[b]{2}{*}{$\begin{array}{l}\text { Estimate } \\
\text { (percent) }\end{array}$} & \multicolumn{4}{|c|}{66.7 percent confidence interval } \\
\hline & & $\begin{array}{c}\text { Peak stream- } \\
\text { flow } \\
\left(\mathrm{ft}^{3} / \mathrm{s}\right)\end{array}$ & \multicolumn{2}{|c|}{$\begin{array}{c}\text { Rank/number } \\
\text { of annual peak } \\
\text { streamflows } \\
\text { in record }\end{array}$} & $\begin{array}{c}\text { Number } \\
\text { of years in } \\
\text { annual peak } \\
\text { analysis }\end{array}$ & & $\begin{array}{l}\text { Lower } \\
\text { (percent) }\end{array}$ & $\begin{array}{r}\text { Upp } \\
\text { (perce }\end{array}$ & & Upper \\
\hline 1 & 07375000 & 32,700 & & $2 / 73$ & 73 & 1.0 & 0.8 & 4.4 & & 139,000 \\
\hline 2 & 07375500 & 120,000 & & $1 / 78$ & 78 & $<0.2$ & $<0.2$ & 2.3 & & 204,000 \\
\hline 3 & 07375800 & 43,000 & & $1 / 60$ & 60 & 0.8 & 0.2 & 3.0 & & 200,000 \\
\hline 4 & 07375960 & 120,000 & & $1 / 44$ & 44 & $<0.2$ & $<0.2$ & 4.1 & & 272,000 \\
\hline 5 & 07376000 & 35,800 & & $1 / 76$ & 76 & $<0.2$ & $<0.2$ & 2.4 & & 57,900 \\
\hline 6 & 07376500 & 22,100 & & $1 / 73$ & 73 & $<0.2$ & $<0.2$ & 2.5 & & 33,800 \\
\hline 7 & 07377000 & 116,000 & & $1 / 68$ & 68 & 1.0 & 0.2 & 2.6 & & 341,000 \\
\hline 8 & 07377500 & 78,000 & & $1 / 74$ & 74 & $<0.2$ & $<0.2$ & 2.4 & & 153,000 \\
\hline 9 & 07378500 & 205,000 & & $1 / 78$ & 78 & $<0.2$ & $<0.2$ & 2.3 & & 307,000 \\
\hline \multirow{4}{*}{$\begin{array}{c}\text { Site iden- } \\
\text { tification } \\
\text { number } \\
\text { (fig. 1) }\end{array}$} & \multirow{4}{*}{$\begin{array}{l}\text { Station } \\
\text { number }\end{array}$} & \multicolumn{9}{|c|}{ Expected peak streamflows for selected AEP with 95 percent confidence intervals } \\
\hline & & \multicolumn{3}{|c|}{$\begin{array}{c}1 \text { percent AEP } \\
\text { (100-year recurrence) }\end{array}$} & \multicolumn{3}{|c|}{$\begin{array}{c}0.5 \text { percent AEP } \\
\text { (200-year recurrence) }\end{array}$} & \multicolumn{3}{|c|}{$\begin{array}{c}0.2 \text { percent AEP } \\
\text { (500-year recurrence) }\end{array}$} \\
\hline & & \multirow{2}{*}{$\begin{array}{c}\text { Estimate } \\
\left(\mathrm{ft}^{3} / \mathrm{s}\right)\end{array}$} & \multicolumn{2}{|c|}{$\begin{array}{l}95 \text { percent confi- } \\
\text { dence interval }\end{array}$} & \multirow{2}{*}{$\begin{array}{l}\text { Estimate } \\
\left(\mathrm{ft}^{3} / \mathbf{s}\right)\end{array}$} & \multicolumn{2}{|c|}{$\begin{array}{c}95 \text { percent } \\
\text { confidence interval }\end{array}$} & \multirow{2}{*}{$\begin{array}{l}\text { Estimate } \\
\left(\mathrm{ft}^{3} / \mathbf{s}\right)\end{array}$} & \multicolumn{2}{|c|}{$\begin{array}{c}95 \text { percent } \\
\text { confidence interval }\end{array}$} \\
\hline & & & Lower & Upper & & Lower & Upper & & Lower & Upper \\
\hline 1 & 07375000 & 34,400 & 23,200 & 66,100 & 43,000 & 27,500 & 92,000 & 56,400 & 33,500 & 139,000 \\
\hline 2 & 07375500 & 76,200 & 56,200 & 121,000 & 89,500 & 63,400 & 153,000 & 108,000 & 72,400 & 204,000 \\
\hline 3 & 07375800 & 41,100 & 25,900 & 88,900 & 52,200 & 31,000 & 128,000 & 69,400 & 38,000 & 200,000 \\
\hline 4 & 07375960 & 52,800 & 33,500 & 122,000 & 65,800 & 39,600 & 174,000 & 86,000 & 47,900 & 272,000 \\
\hline 5 & 07376000 & 25,200 & 19,300 & 37,500 & 28,600 & 21,300 & 45,500 & 33,300 & 23,500 & 57,900 \\
\hline 6 & 07376500 & 12,500 & 9,600 & 19,800 & 14,700 & 10,800 & 25,100 & 17,800 & 12,500 & 33,800 \\
\hline 7 & 07377000 & 118,000 & 84,600 & 199,000 & 139,000 & 95,100 & 253,000 & 169,000 & 108,000 & 341,000 \\
\hline 8 & 07377500 & 47,600 & 34,100 & 82,100 & 57,400 & 39,300 & 108,000 & 71,900 & 46,300 & 153,000 \\
\hline 9 & 07378500 & 136,000 & 104,000 & 200,000 & 154,000 & 114,000 & 243,000 & 180,000 & 126,000 & 307,000 \\
\hline
\end{tabular}




\section{Estimated Magnitudes and Flood Probabilities of Peak Streamflows}

New peaks of record streamflow were experienced at 10 of the 16 USGS streamflow-gaging stations listed in table 3 . The remaining six streamflow-gaging stations experienced peak streamflows that ranked in the top five for the period of record. Streamflow from the August 2016 flood event exceeded streamflow from the March 2016 flood event for 15 of the 16 USGS streamflow-gaging stations selected in this study. The flood-frequency statistics computed for this study are presented in table 5. The AEP estimates for the analyzed streamflow-gaging stations ranged from less than 0.2 to 1 percent. The number of years of peak streamflow record for analyzed streamflow-gaging stations ranged from 44 to 78 , with the mean number of 69 years.

\section{Flood-Inundation Maps}

Twelve flood-inundation maps were created for communities in Louisiana (fig. 2). Each map presents the areal extent of the flood waters. The HWMs used to create the inundation maps and associated information can be accessed at the USGS STN website (USGS, 2016) and are provided in Heal and Watson (2017). Digital datasets of the inundation area, modeling boundary, water depth rasters, and final map products are available for download at Heal and Watson (2017). The locations of specific flood-inundation maps are described in the following sections.

\section{Amite River}

The Amite River has its headwaters in southwestern Mississippi and flows for approximately 117 miles (mi) to Lake Maurepas in southeastern Louisiana. Multiple communities in East Feliciana, St. Helena, East Baton Rouge, Livingston, Ascension, St. James, and St. John the Baptist Parishes are located along a 68-mi reach of the Amite River, including Denham Springs, Port Vincent, French Settlement, and Maurepas. A total of 194 HWMs were documented along this reach, and 167 were surveyed and used to develop the inundation map. The depths of water at the HWMs ranged from 0.6 to $9.6 \mathrm{ft}$ aboveground, and the elevations ranged from 4.3 to $194.3 \mathrm{ft}$ above NAVD 88 .

The USGS operates 7 streamflow-gaging stations on the Amite River and 19 streamflow-gaging stations on smaller tributaries that were used in the analysis to create the inundation map. The Amite River streamflow-gaging stations used in the creation of the inundation maps include:

1. Amite River near Darlington, La. (USGS 07377000), recorded a peak stage of $22.54 \mathrm{ft}$ gage datum and a water-surface elevation of $168.35 \mathrm{ft}$ above NGVD 29 on August 12, 2016;
2. Amite River at Grangeville, La. (USGS 07377150), recorded a peak stage of $44.62 \mathrm{ft}$ gage datum and a water-surface elevation of $116.46 \mathrm{ft}$ above NGVD 29 on August 13, 2016;

3. Amite River at Magnolia, La. (USGS 07377300), recorded a peak stage of $58.56 \mathrm{ft}$ gage datum and a water-surface elevation of $57.42 \mathrm{ft}$ above NAVD 88 on August 13, 2016;

4. Amite River near Denham Springs, La. (USGS 07378500), recorded a peak stage of $46.2 \mathrm{ft}$ gage datum and a water-surface elevation of $44.85 \mathrm{ft}$ above NAVD 88 on August 14, 2016;

5. Amite River at Port Vincent, La. (USGS 07380120), recorded a peak stage of $17.45 \mathrm{ft}$ gage datum and a water- surface elevation of $16.09 \mathrm{ft}$ above NAVD 88 on August 15, 2016;

6. Amite River near French Settlement, La. (USGS 07380200), recorded a peak stage of $9.21 \mathrm{ft}$ gage datum and a water-surface elevation of $8.30 \mathrm{ft}$ above NAVD 88 on August 16, 2016; and

7. Amite River at Highway 22 near Maurepas, La. (USGS 07380215), recorded a peak stage of $5.73 \mathrm{ft}$ gage datum and a water-surface elevation of $4.48 \mathrm{ft}$ above NAVD 88 on August 17, 2016.

Precipitation ranged from about 5 to 26 in. within the Amite River Basin over the duration of the event. The aerial extent of flood inundation for the upper Amite River, which extends from near the Mississippi-Louisiana State border to the confluence with the Comite River, is shown in figure 3. The aerial extent of flood inundation for the lower Amite River, which extends from the confluence with the Comite River to Lake Maurepas, is shown in figure 4. The aerial extent of flood inundation for the combined upper and lower Amite River reaches is shown in figure 5.

\section{Comite River}

The Comite River flows south through the community of Baton Rouge (and surrounding communities) in East Baton Rouge and East Feliciana Parishes, in the northern part of Baton Rouge. The extent of the inundation map is a 33-mi reach of the Comite River from Clinton through Baton Rouge. A total of 74 HWMs were documented in the Comite River Basin, and 59 HWMs were surveyed along the Comite River; 35 of the HWMs were used in the creation of an inundation depth map for the city of Baton Rouge and surrounding areas. Seventeen HWMs were documented but were not surveyed. Some of the unsurveyed HWMs were used in the creation of the inundation depth map with height aboveground estimated from the lidar DEM. The measured depths of water at the HWMs ranged from 0.2 to $5.9 \mathrm{ft}$ aboveground, and the elevations ranged from 63.5 to $79.3 \mathrm{ft}$ above NAVD 88 . 


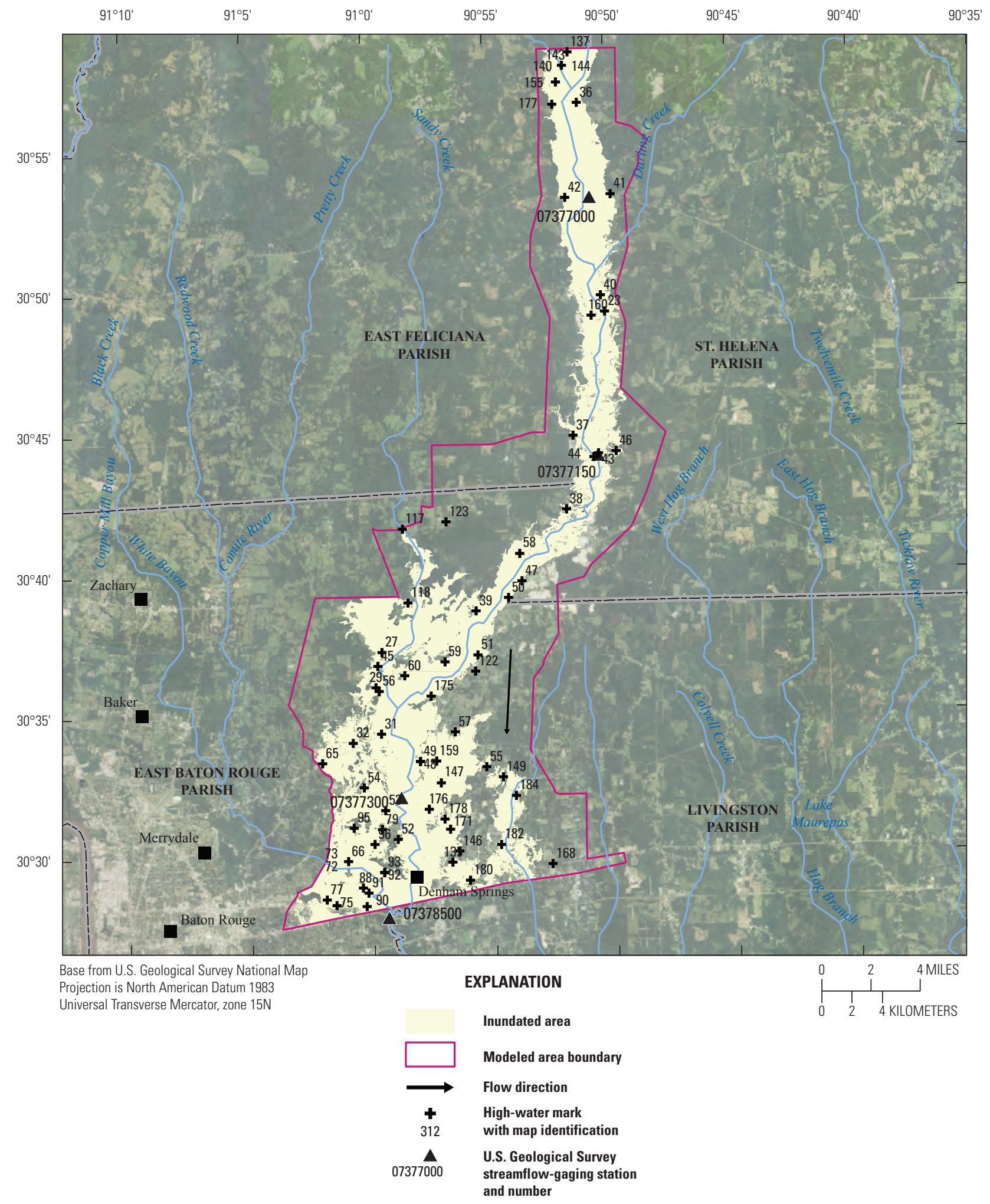

Figure 3. Flood-inundation map of the upper reach of the Amite River, Louisiana, August 2016. 


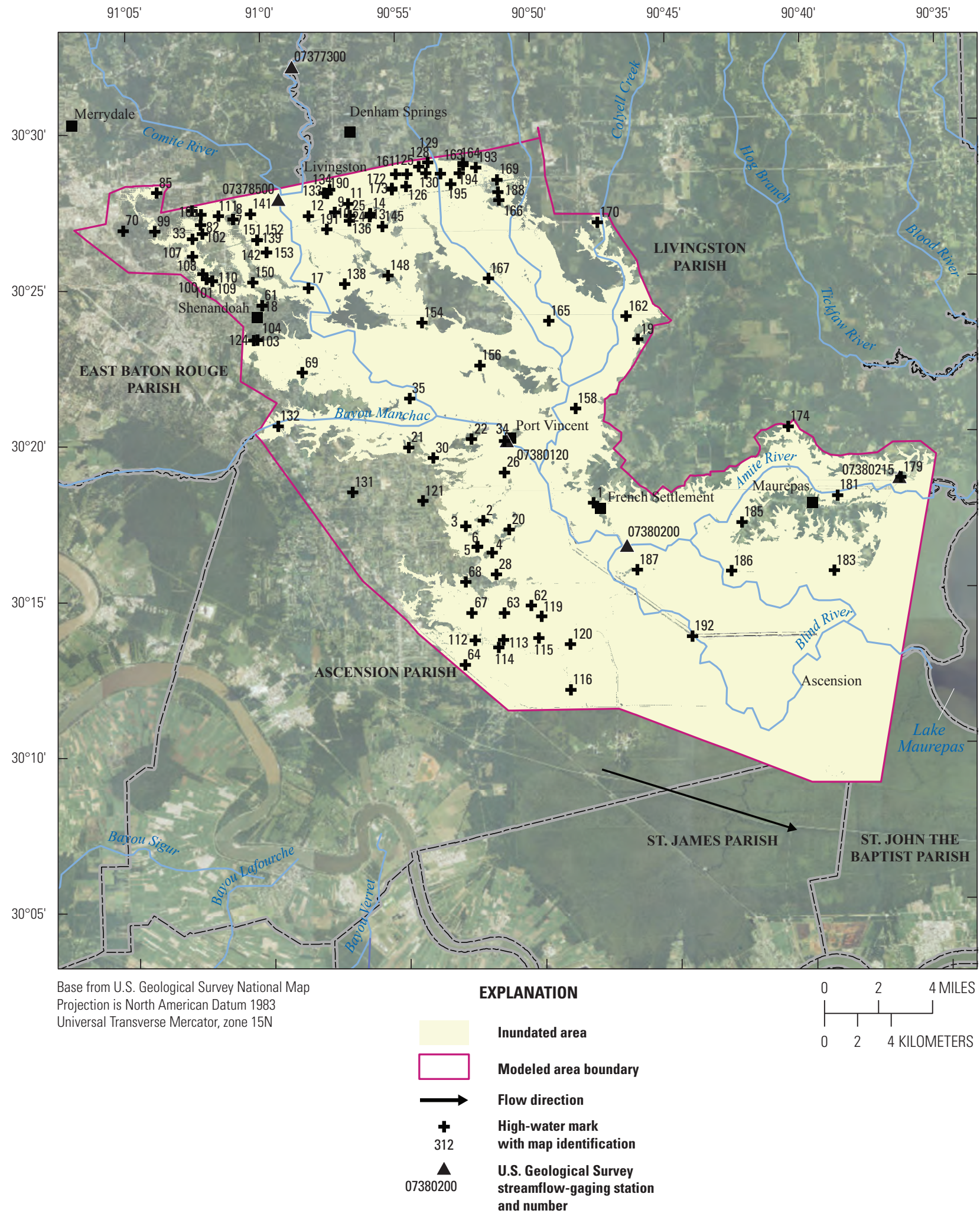

Figure 4. Flood-inundation map of the lower reach of the Amite River, Louisiana, August 2016. 


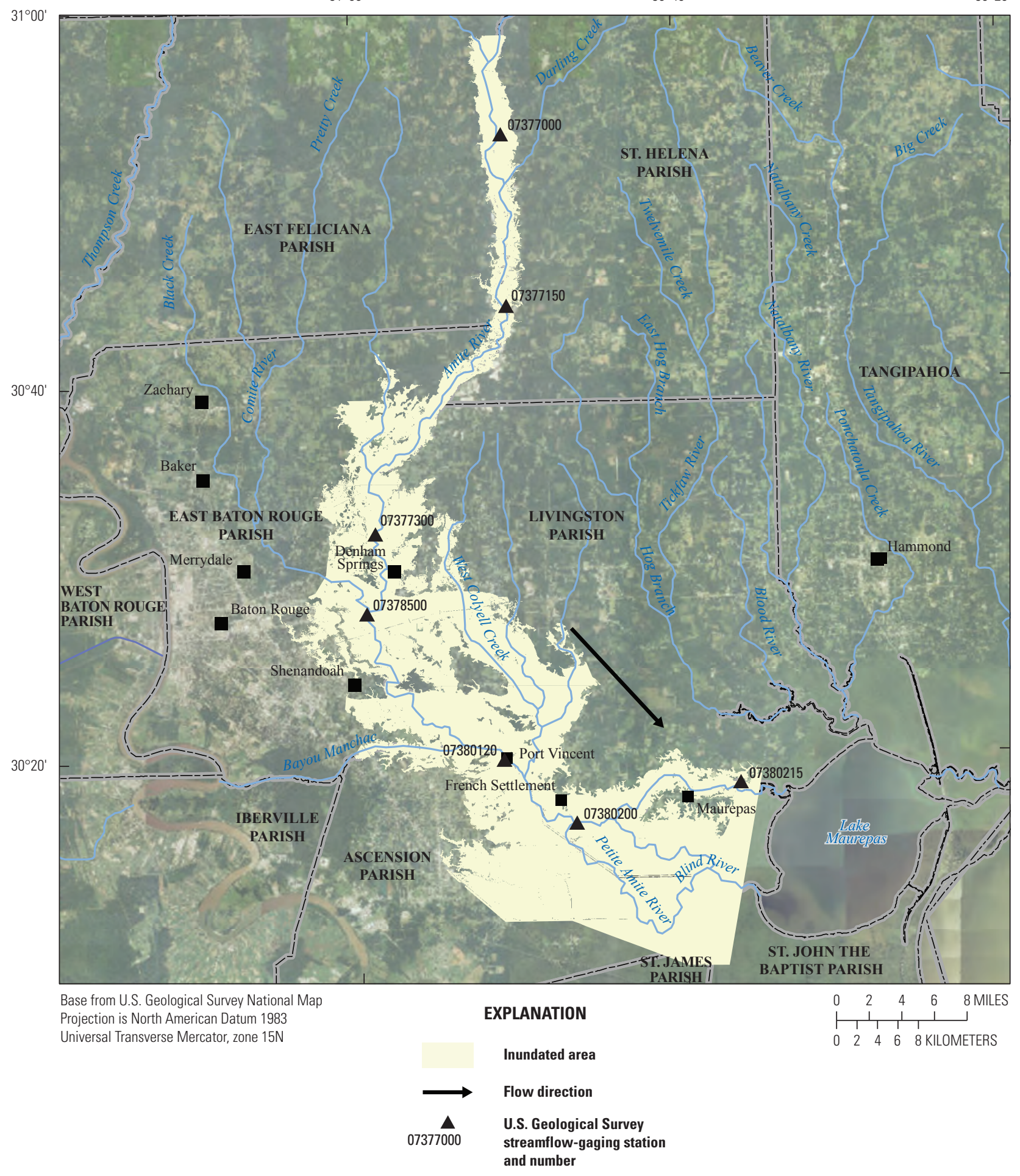

Figure 5. Flood-inundation map of the upper and lower reaches of the Amite River, Louisiana, August 2016. 
The USGS streamflow-gaging station Comite River at Point Hudson-Pride Road near Milldale, La. (USGS 07377600), recorded a peak stage of $38.98 \mathrm{ft}$ on August 13, 2016. The USGS streamflow-gaging station Comite River at Hooper Road near Baton Rouge, La. (USGS 07377870), recorded a peak stage of $31.56 \mathrm{ft}$ on August 13, 2016. During the August flood event, 18 in. of rainfall was reported at the Baton Rouge Metro Airport for the period of August 11-14, 2016. By comparison, the average annual precipitation at the airport is 53.54 in. (National Oceanic and Atmospheric Administration, 2016e). Precipitation ranged from about 6 to 26 in. within the Comite River Basin over the duration of the event. The aerial extent of flood inundation for this location is shown in figure 6.

\section{Mermentau River and Tributaries}

The Mermentau River flows southwest through the community of Mermentau, La., $40 \mathrm{mi}$ west of Lafayette (fig. 2) in Jefferson Davis, Acadia, Cameron, and Vermilion Parishes. The extent of the inundation map is a 16.3-mi reach of the Mermentau River from Mermentau through Lake Arthur.

A total of 15 HWMs was documented in the Mermentau River Basin; 14 HWMs were documented and surveyed along the Mermentau River, and 12 of the HWMs were used in the creation of the inundation depth map in the community of Mermentau and surrounding areas. One HWM was not surveyed. The unsurveyed HWM was used in the creation of the inundation depth map in which height aboveground was estimated from the lidar DEM. The measured depths of water at the HWM ranged from 0.75 to $5.9 \mathrm{ft}$ aboveground, and the elevations ranged from 4.5 to $13.7 \mathrm{ft}$ above NAVD 88 .

The USGS operates three streamflow-gaging stations on the Mermentau River and surrounding tributaries that were used in the creation of the inundation maps. The Mermentau River streamflow-gaging stations used in the creation of the inundation maps include:

1. Mermentau River at Mermentau, La. (USGS 08012150), recorded a peak stage of $10.82 \mathrm{ft}$ gage datum and water-surface elevation of $11.4 \mathrm{ft}$ above NGVD 29 on August 18, 2016;

2. Bayou Des Cannes near Eunice, La. (USGS 08010000), recorded a peak stage of $22.37 \mathrm{ft}$ and water-surface elevation of $37.21 \mathrm{ft}$ above NGVD 29 on August 15, 2016; and

3. Bayou Nezpique near Basile, La. (USGS 08012000), recorded a peak stage of $25.81 \mathrm{ft}$ and water-surface elevation of $29.39 \mathrm{ft}$ above NAVD 88 on August 16, 2016.

During the August flood event, 16.94 in. of rainfall was reported at the Jennings Weather Station (5.6 mi northwest of Mermentau) for the period of August 11-14, 2016. By comparison, the departure from normal monthly precipitation is 18.83 in. (National Oceanic and Atmospheric Administration, 2016e). Precipitation ranged from about 5 to $22 \mathrm{in}$. within the Mermentau River Basin over the duration of the event. The aerial extent of flood inundation for this location is shown in figure 7. The locations of streamflow-gaging stations USGS 08010000 and USGS 08012000 are shown on figure 8.

\section{Bayou des Cantes}

Bayou des Cantes, a tributary to the Mermentau River, flows south toward Mermentau, La., through Eunice, La., 40 mi west of Lafayette (shown on fig. 2) in Jefferson Davis, Acadia, Evangeline, and St. Landry Parishes. The extent of the inundation map is a 38-mi reach of Bayou des Cantes from Eunice to the confluence with the Mermentau River.

A total of 14 HWMs were documented in the Bayou des Cantes Basin; 12 HWMs were surveyed along the Bayou des Cantes and 9 of the HWMs were used in the creation of the inundation depth map in the community of Mermentau and surrounding areas. Two HWMs were not surveyed. Both of the unsurveyed HWMs were used in the creation of the inundation depth map in which height aboveground was estimated from the lidar DEM. The measured depths of water at the HWMs ranged from 2.09 to $5.1 \mathrm{ft}$ aboveground, and the elevations ranged from 10.9 to $51.0 \mathrm{ft}$ above NAVD 88 .

Two USGS streamflow-gaging stations were used for the inundation analysis: (1) Bayou Des Cannes near Eunice, La. (USGS 08010000), recorded a peak stage of $37.09 \mathrm{ft}$ on August 15, 2016, and (2) Mermentau River at Mermentau, La. (USGS 08012150), recorded a peak stage of $11.36 \mathrm{ft}$ on August 18, 2016. The aerial extent of flood inundation for this location is shown in figure 8 .

\section{Bayou Nezpique}

Bayou Nezpique, a tributary to the Mermentau River, flows south toward Mermentau, La., through Jennings, La., 40.9 mi. west of Lafayette (shown on fig. 2) in Jefferson Davis, Acadia, Allen, and Evangeline Parishes. The extent of the inundation map is a 33-mi reach of Bayou Nezpique from Basile to Mermentau near Lake Arthur.

A total of 13 HWMs were documented in the Bayou Nezpique Basin; 4 HWMs were surveyed along the Bayou Nezpique, and 11 of the HWMs were used in the creation of the inundation depth map in the community of Mermentau and surrounding areas. Nine HWMs were not surveyed. Some of those nine unsurveyed HWMs were used in the creation of the inundation depth map, in which height aboveground was estimated from the lidar DEM. The measured depths of water at the HWMs ranged from 1.3 to $6.7 \mathrm{ft}$ aboveground, and the elevations ranged from 10.5 to $44.5 \mathrm{ft}$ above NAVD 88 .

Two USGS streamflow-gaging stations were used in the inundation analysis: (1) Bayou Nezpique near Basile, La. (USGS 08012000), recorded a peak stage of $25.81 \mathrm{ft}$ on August 


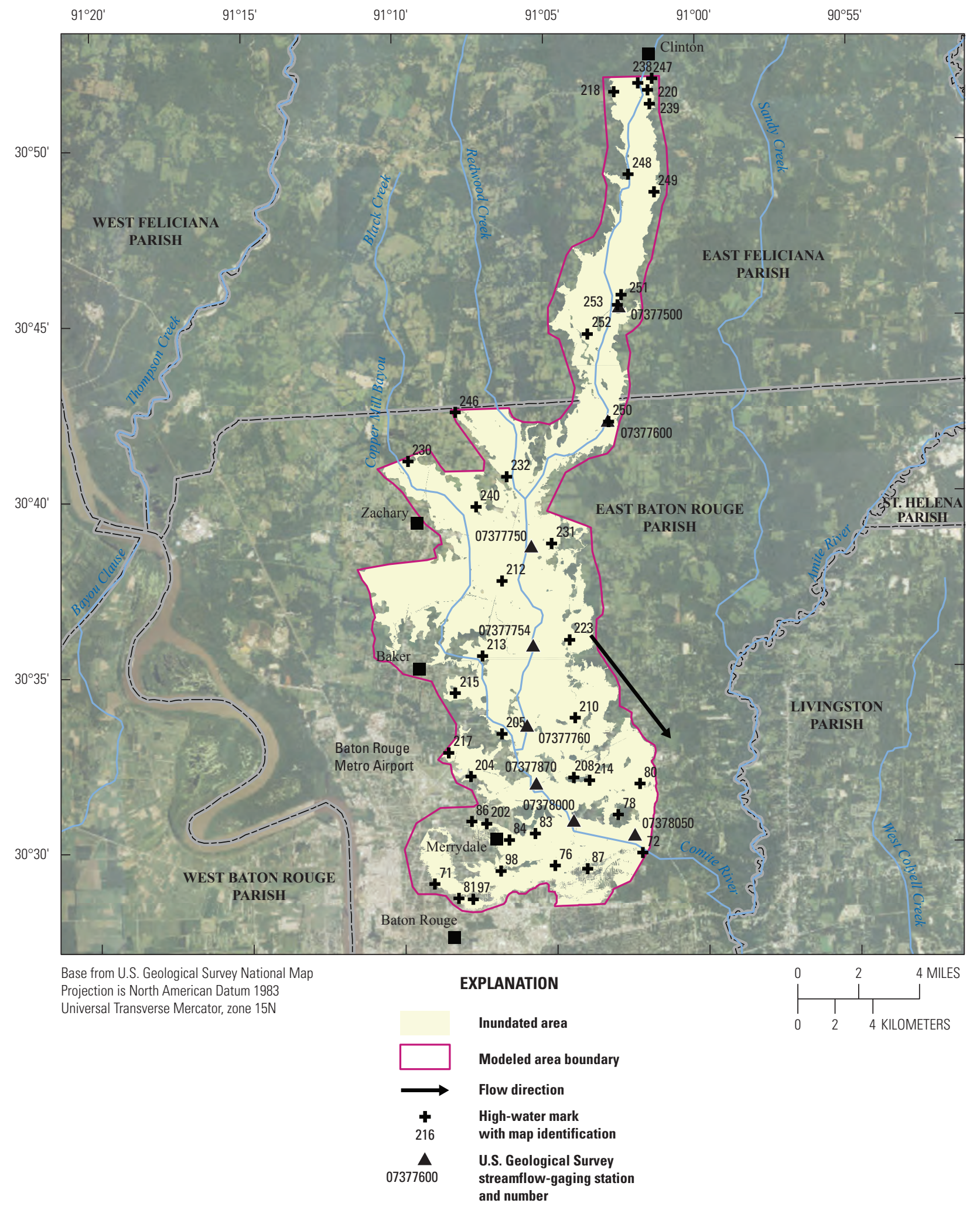

Figure 6. Flood-inundation map of Comite River, Louisiana, August 2016. 


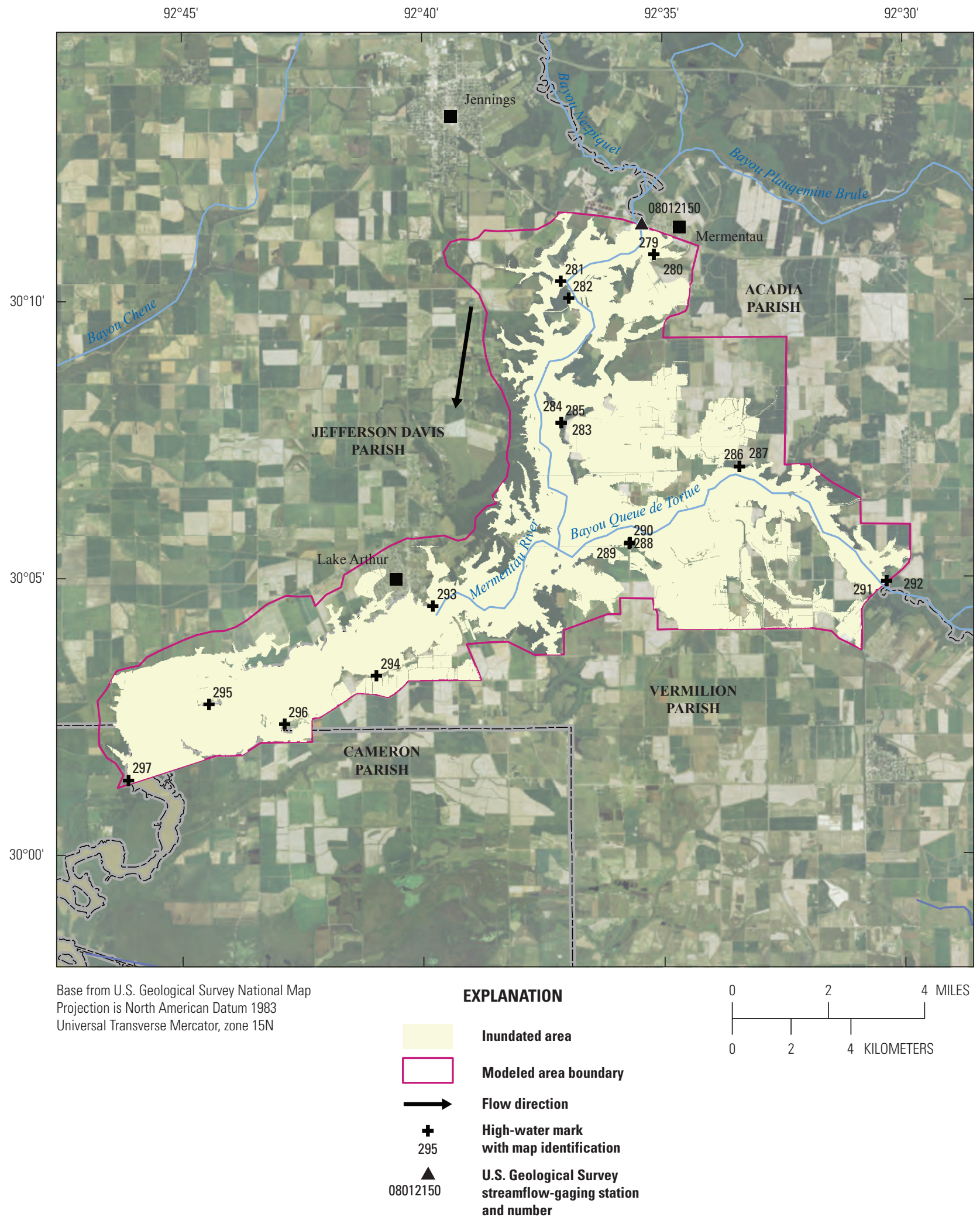

Figure 7. Flood-inundation map of Mermentau River, Louisiana, August 2016. 


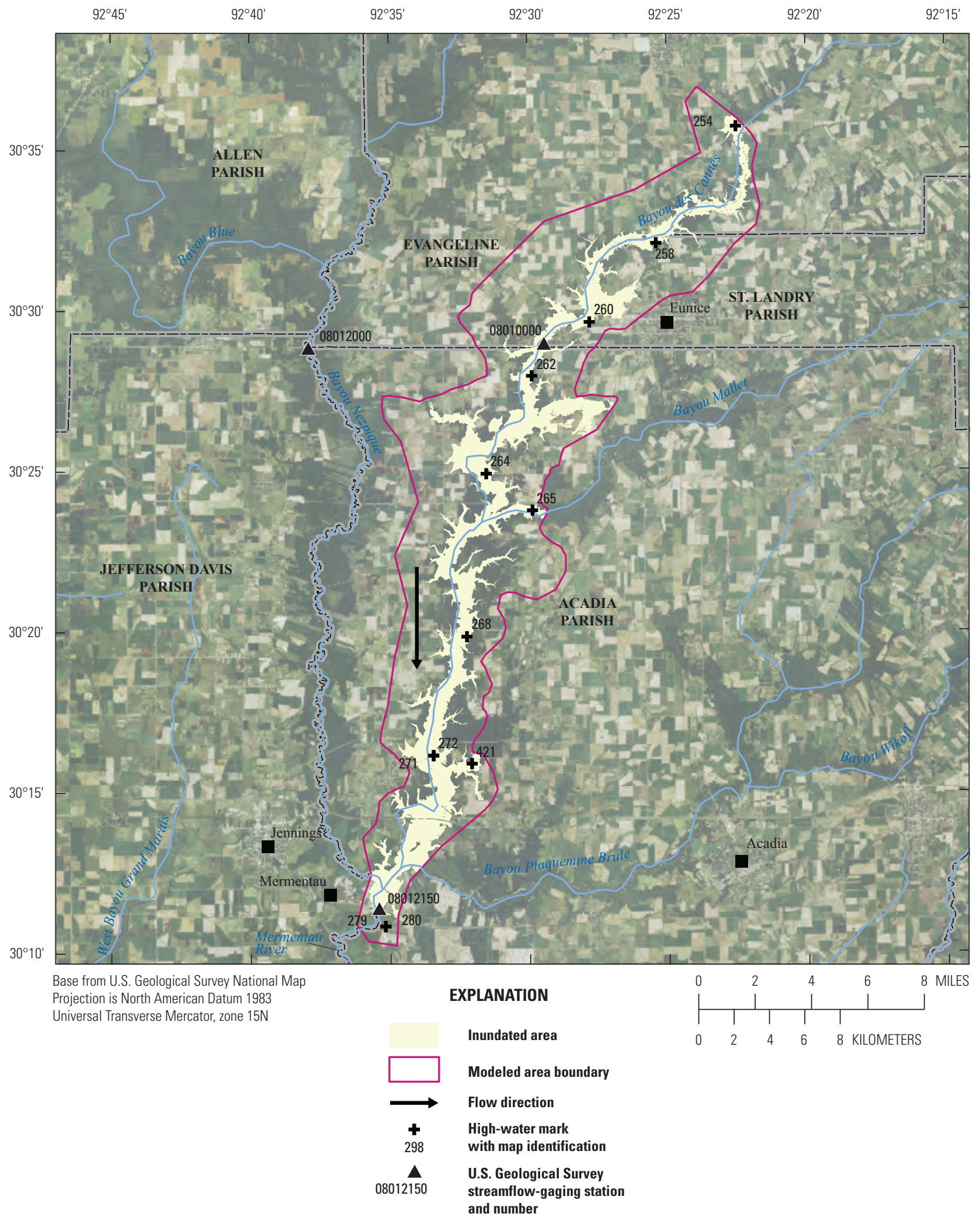

Figure 8. Flood-inundation map of Bayou des Cantes, tributary to Mermentau River, Louisiana, August 2016. 
16, 2016, and (2) Mermentau River at Mermentau, La. (USGS 08012150), recorded a peak stage of $11.36 \mathrm{ft}$ on August 18, 2016. The aerial extent of flood inundation for this location is shown in figure 9.

\section{Bayou Plaquemine Brule}

Bayou Plaquemine Brule, a tributary to the Mermentau River, flows west toward Mermentau, La., through Crowley and Estherwood, La., $32.2 \mathrm{mi}$ west of Lafayette (shown on fig. 2 ) in Jefferson Davis and Acadia Parishes. The extent of the inundation map is a 26-mi reach of Bayou Plaquemine Brule from Rayne to Mermentau near Lake Arthur.

A total of nine HWMs were documented in the Bayou Plaquemine Brule Basin; 8 HWMs were surveyed along Bayou Plaquemine Brule, and 6 of the HWMs were used in the creation of the inundation depth map in the community of Mermentau and surrounding areas. One HWM was not surveyed. The measured depth of water at the HWMs ranged from 2.3 to $6.3 \mathrm{ft}$ aboveground, and the elevations ranged from 8.9 to $26.6 \mathrm{ft}$ above NAVD 88 . The aerial extent of flood inundation for this location is shown in figure 10 .

\section{Tangipahoa River}

The Tangipahoa River flows generally south to southeast through Tangipahoa Parish into Lake Pontchartrain. The extent of the inundation map is a 40-mi reach of the Tangipahoa River from Kentwood to Ponchatoula/Hammond in Tangipahoa Parish. A total of 29 HWMs was documented along the Tangipahoa River, and 20 of the HWMs were surveyed and used to create the inundation map. The depths of water at the HWMs ranged from 0.6 to $10.6 \mathrm{ft}$ aboveground, and the elevations ranged from 17.22 to $128.13 \mathrm{ft}$ above NAVD 88. The USGS operates four streamflow-gaging stations on the Tangipahoa River that were used in the creation of the inundation maps. The streamflow-gaging stations used in the creation of the inundation maps include:

1. Tangipahoa River near Kentwood, La. (USGS 07375300), recorded a peak stage of $16.30 \mathrm{ft}$ gage datum and water-surface elevation of $196.37 \mathrm{ft}$ above NGVD 29 on August 12, 2016;

2. Tangipahoa River near Amite, La. (USGS 07375430), recorded a peak stage of $29.28 \mathrm{ft}$ gage datum and water-surface elevation of $109.28 \mathrm{ft}$ above NAVD 88 on August 12, 2016;

3. Tangipahoa River at Robert, La. (USGS 07375500), recorded a peak stage of $27.33 \mathrm{ft}$ gage datum and a water-surface elevation of $33.93 \mathrm{ft}$ above NAVD 88 on August 13, 2016; and

4. Tangipahoa River near Ponchatoula, La. (USGS 07375650), recorded a peak stage of $21.87 \mathrm{ft}$ gage datum and a water-surface elevation of $19.18 \mathrm{ft}$ above NAVD 88 on August 14, 2016.

Precipitation ranged from about 6 to 17 in. within the Tangipahoa River Basin over the duration of the event. The aerial extent of flood inundation for this location is shown in figure 11 .

\section{Tickfaw River}

The Tickfaw River flows south from southwestern Mississippi through St. Helena and Livingston Parish into Lake Maurepas. The extent of inundation mapping has been separated into two reaches because of the location of the HWMs that were surveyed. One map includes a 33-mi reach of the upper to middle Tickfaw River from Liverpool in St. Helena Parish to Holden in Livingston Parish. The second map is a 7-mi reach in Killian, located in Livingston Parish, flowing to the mouth of the river at Lake Maurepas. A total of 95 HWMs were documented along the Tickfaw River; 58 of the HWMs were surveyed and used to create the inundation map for the upper reach, and 9 were surveyed and used to create the inundation map for the area around the mouth of the river. The depths of water for the upper to middle reach at the HWMs ranged from 0.91 to $9.6 \mathrm{ft}$ aboveground, and the elevations ranged from 35.2 to $218.6 \mathrm{ft}$ above NAVD 88 . The depths of water for the reach near the mouth of the river at the HWMs ranged from 0.73 to $5.97 \mathrm{ft}$ aboveground, and the elevations ranged from 6.48 to $18.2 \mathrm{ft}$ above NAVD 88 .

The USGS operates three streamflow-gaging stations on the Tickfaw River that were used in the creation of the inundation maps. The streamflow-gaging stations used in the creation of the inundation maps include:

1. Tickfaw River at Liverpool, La. (USGS 07375800), recorded a peak stage of $13.87 \mathrm{ft}$ gage datum and a water-surface elevation of $218.31 \mathrm{ft}$ above NGVD 29 on August 12, 2016;

2. Tickfaw River at Montpelier, La. (USGS 07375960), recorded a peak stage of $26.04 \mathrm{ft}$ gage datum and a water-surface elevation of $112.92 \mathrm{ft}$ above NAVD 88 on August 12, 2016; and

3. Tickfaw River at Holden, La. (USGS 07376000), recorded a peak stage of $22.16 \mathrm{ft}$ gage datum and a water-surface elevation of $40.81 \mathrm{ft}$ above NAVD 88 on August 13, 2016.

The Tickfaw River watershed experienced a loss of flow to the neighboring Natalbany River watershed between the Tickfaw River streamflow-gaging stations in Montpelier and Holden. Precipitation ranged from about 6 to 24 in. within the Tickfaw River Basin over the duration of the event. The aerial extent of flood inundation for this location is shown in figures 12 and 13. 


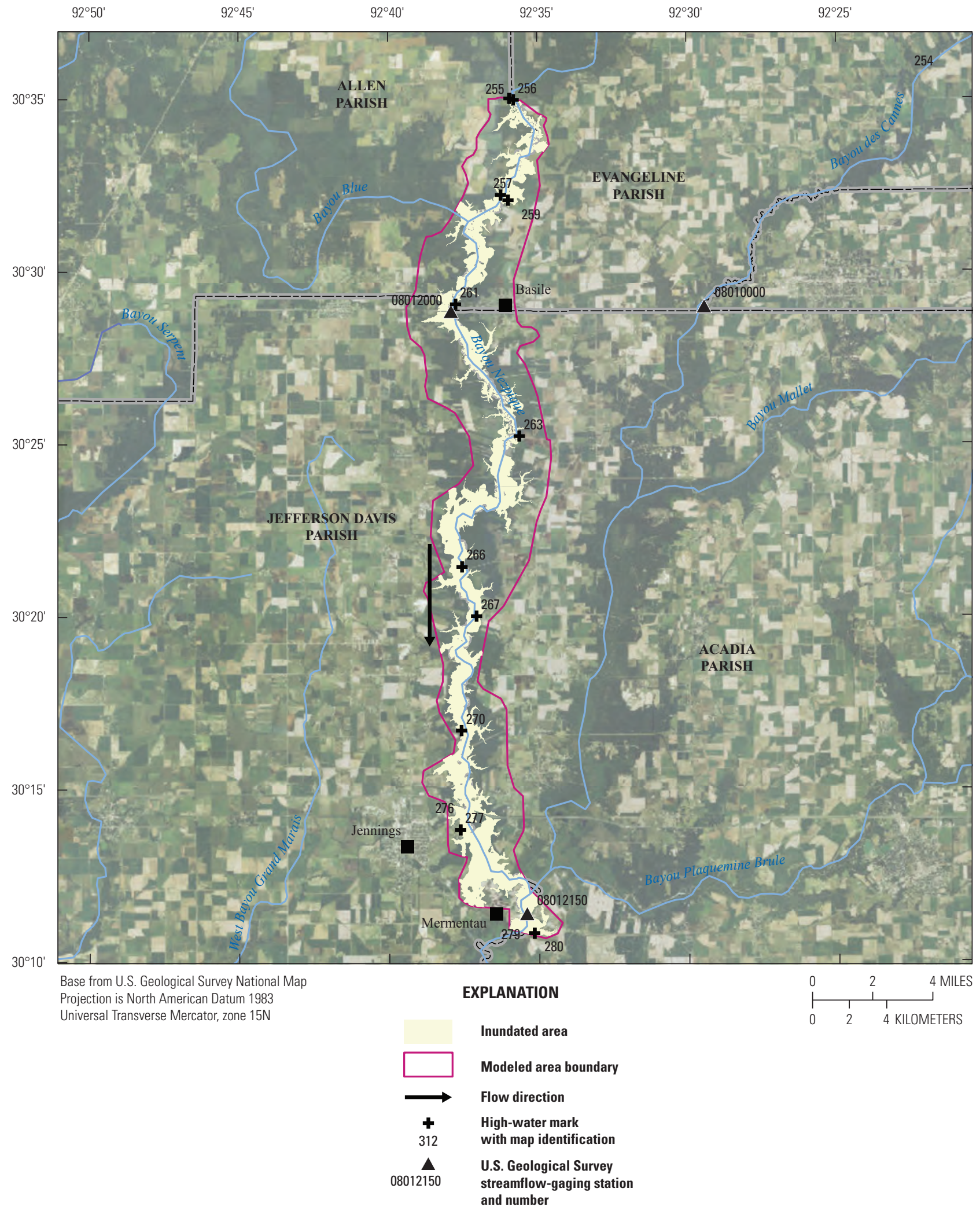

Figure 9. Flood-inundation map of Bayou Nezpique, tributary to Mermentau River, Louisiana, August 2016. 


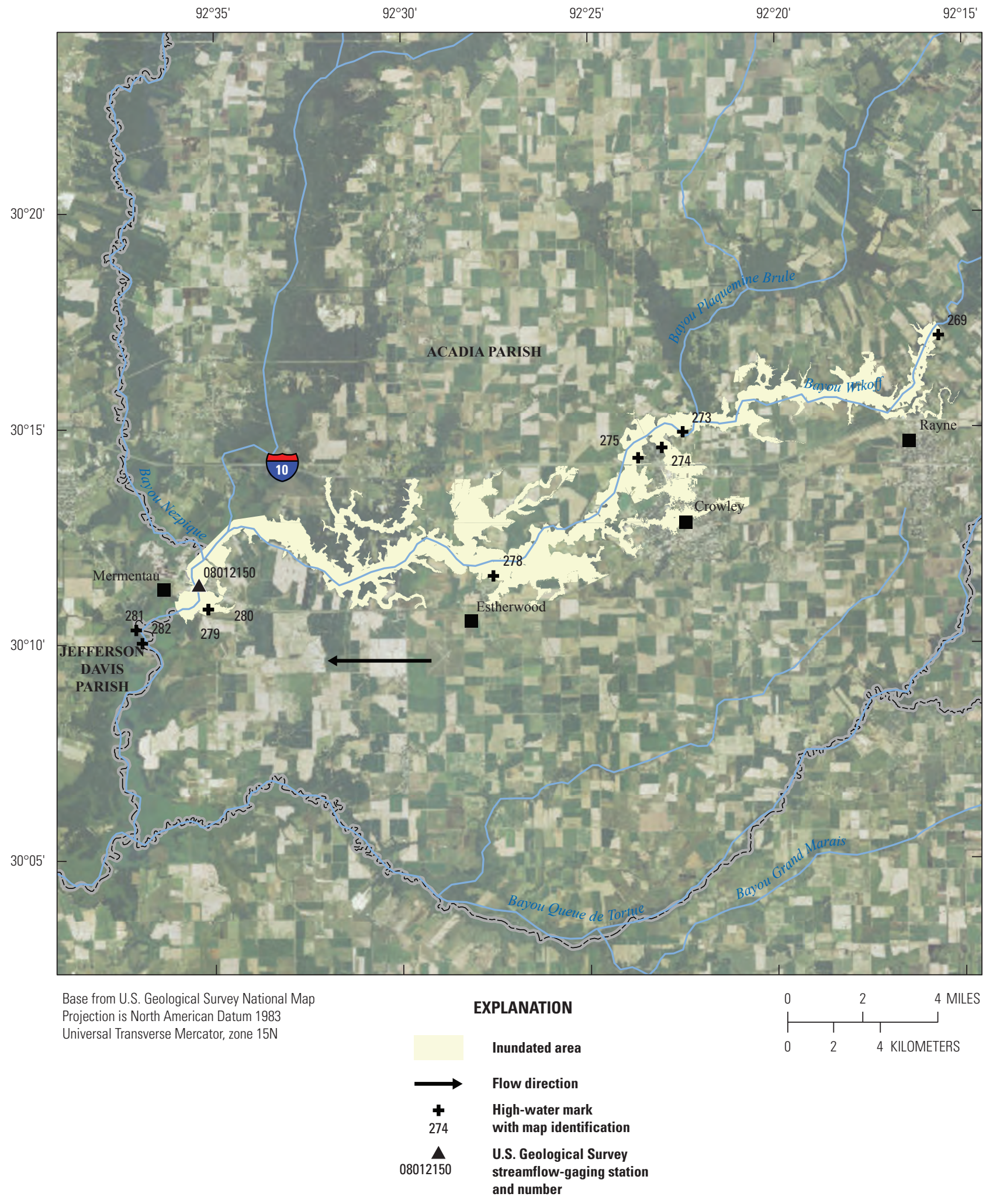

Figure 10. Flood-inundation map of Bayou Plaquemine Brule, tributary to Mermentau River, Louisiana, August 2016. 


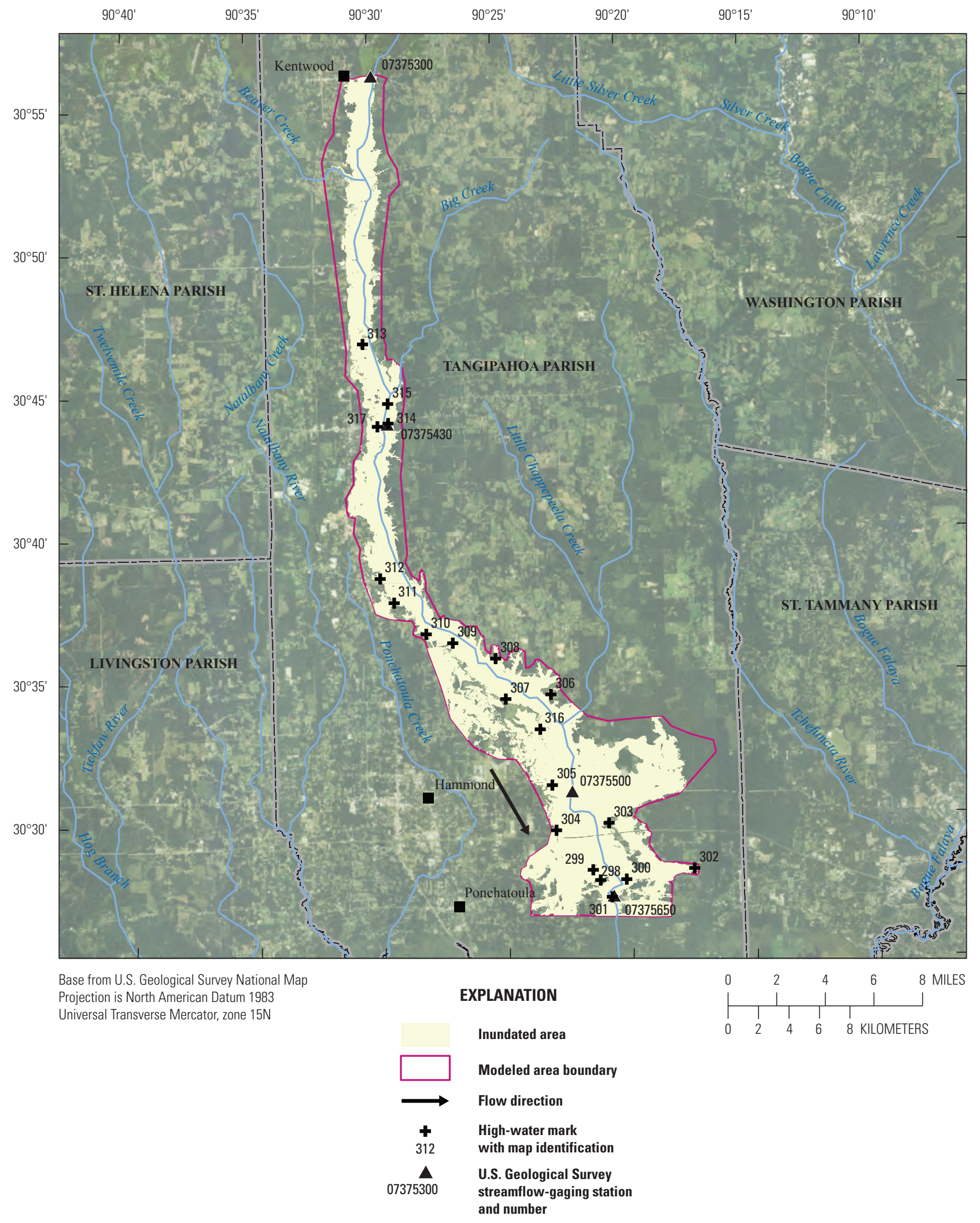

Figure 11. Flood-inundation map of Tangipahoa River, Louisiana, August 2016. 


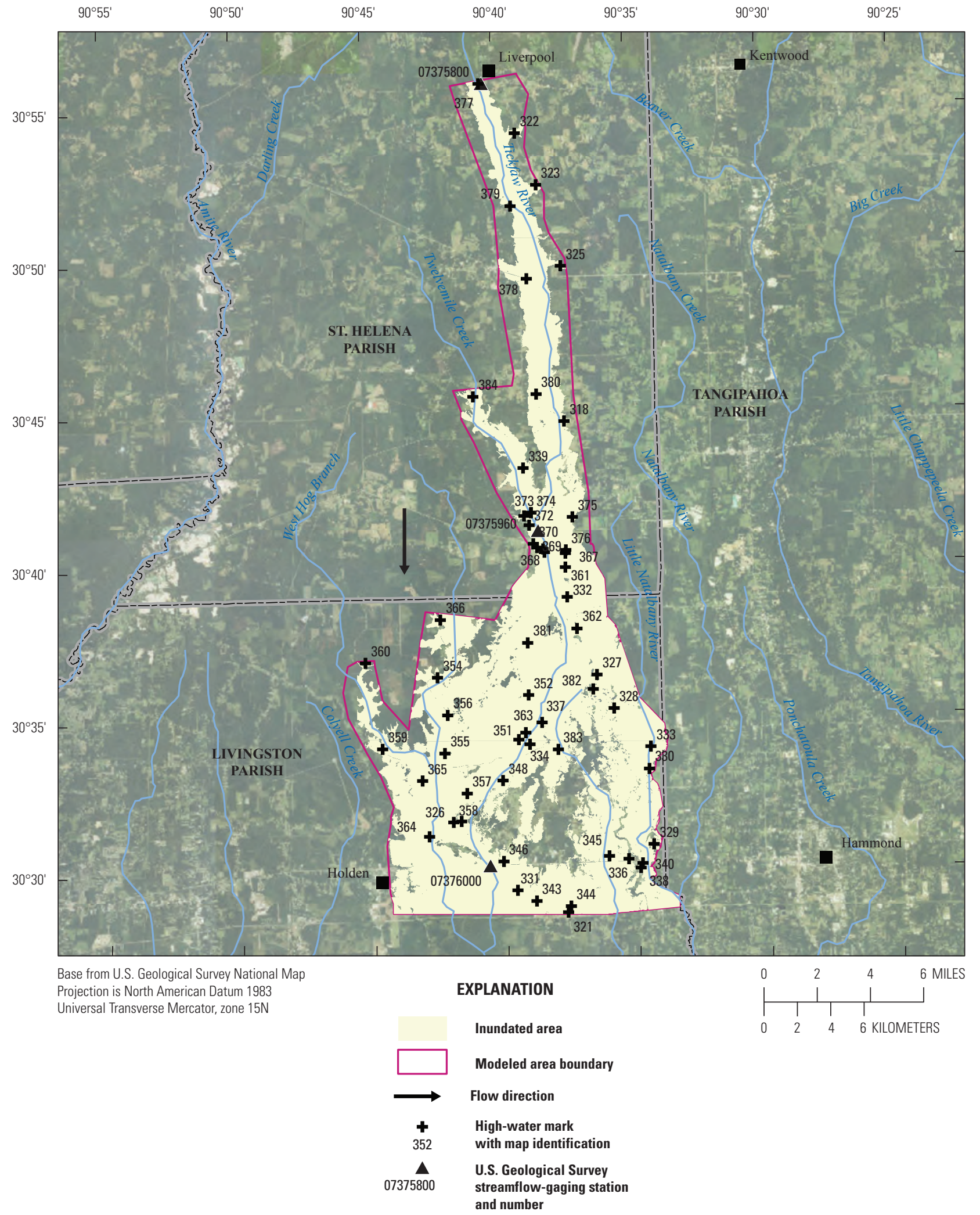

Figure 12. Flood-inundation map of the upper reach of Tickfaw River, Louisiana, August 2016. 


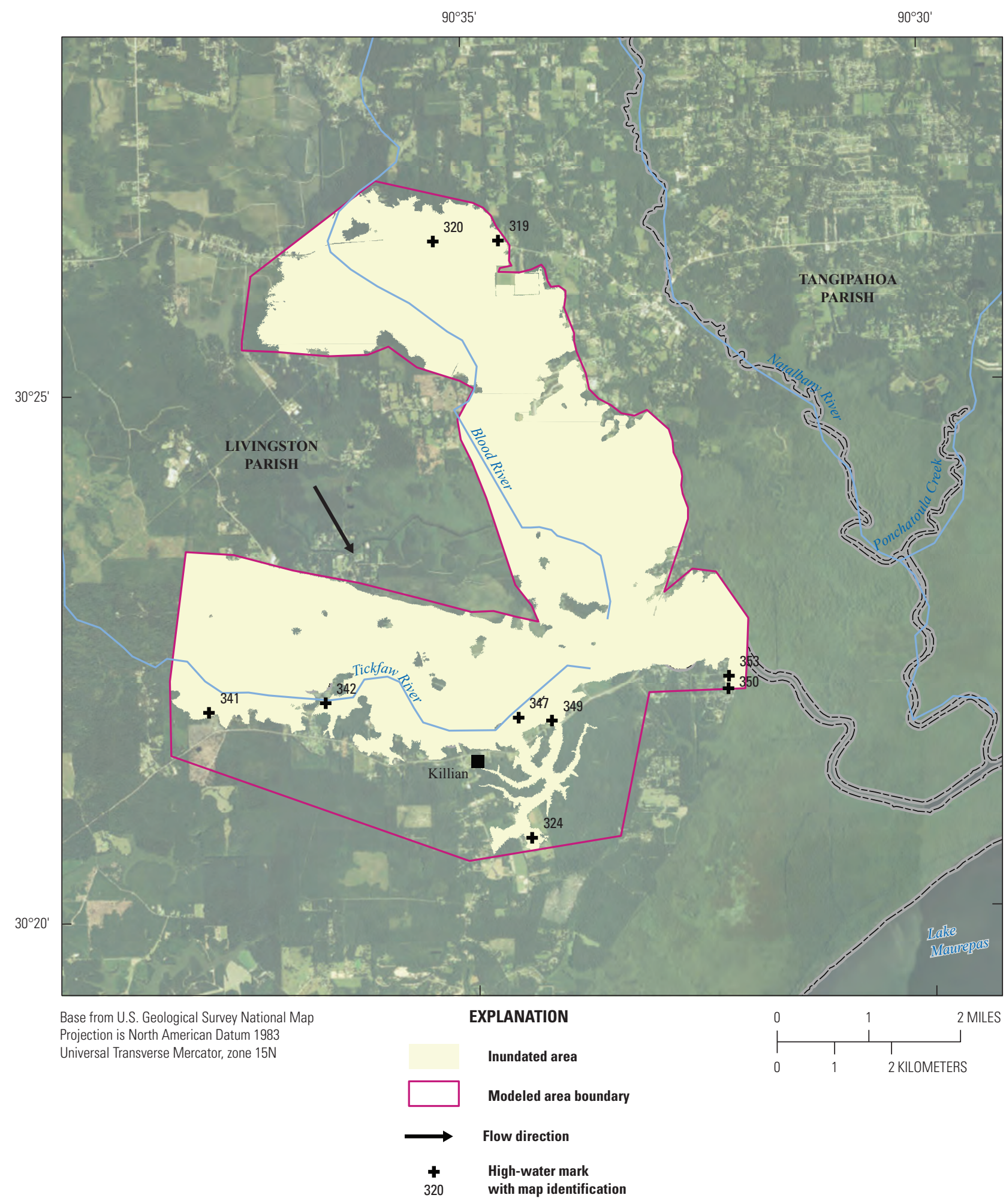

Figure 13. Flood-inundation map of area around the mouth of Tickfaw River, Louisiana, August 2016. 


\section{Vermilion River}

The Vermilion River is formed by several small bayous in southern Louisiana and flows south for approximately 70 mi to Vermilion Bay at the Gulf of Mexico (shown on fig. 2). Several communities in St. Martin, Lafayette, and Vermilion Parishes are located along a 34-mi reach of the Vermilion River, including Lafayette, Abbeville, and Perry. During heavy rainfall events, flow direction of the Vermilion River in the Lafayette area can reverse because of the large area of urbanization. This was confirmed by flood profiles from the August flood event. A total of 64 HWMs were documented along this reach, and 36 were surveyed and used to develop the inundation map. The depths of water at the HWMs ranged from 0.7 to $6.8 \mathrm{ft}$ aboveground, and the elevations ranged from 7.0 to $30.5 \mathrm{ft}$ above NAVD 88. The USGS operates four streamflow-gaging stations on the Vermilion River that were used in the creation of the inundation maps. The streamflowgaging stations used in the creation of the inundation maps include:

1. Vermilion River near Lafayette, La. (USGS 07386850), recorded a peak stage of $15.01 \mathrm{ft}$ gage datum and a water-surface elevation of $15.01 \mathrm{ft}$ above NAVD 88 on August 17, 2016;

2. Vermilion River at Surrey St. at Lafayette, La. (USGS 07386880), recorded a peak stage of $17.62 \mathrm{ft}$ gage datum and a water-surface elevation of $14.88 \mathrm{ft}$ above NAVD 88 on August 15, 2016;

3. Vermilion River at Highway 733 near Lafayette, La. (USGS 07386940), recorded a peak stage of $19.91 \mathrm{ft}$ gage datum and a water-surface elevation of $19.91 \mathrm{ft}$ above NAVD 88 on August 13, 2016; and

4. Vermilion River at Perry, La. (USGS 07386980), recorded a peak stage of $13.75 \mathrm{ft}$ gage datum and a water-surface elevation of $10.29 \mathrm{ft}$ above NGVD 29 on August 14, 2016.

Precipitation ranged from about 12 to 26 in. within the Vermilion River Basin over the duration of the event. The aerial extent of flood inundation for this reach of the Vermilion River is shown in figure 14.

\section{Flood Damages}

During August 2016, flooding on numerous streams and rivers in Louisiana resulted in at least 13 fatalities and damage to more than 140,000 homes (National Oceanic and Atmospheric Administration, 2016b). Monetary losses resulting from damages to numerous homes, businesses, and infrastructure were estimated to be $\$ 10$ billion (National Oceanic and Atmospheric Administration, 2016a). This storm event has been regarded as the worst natural disaster in the United States since Hurricane Sandy on the east coast in 2012 (Yan and Flores, 2016).

\section{Summary}

During the period of August 11-14, 2016, a slow-moving area of low pressure and a high amount of atmospheric moisture over Louisiana and southwestern Mississippi resulted in heavy rainfall with amounts of 20 to more than 31 inches that caused historic flooding in numerous stream basins in Louisiana. New peaks of record streamflow were experienced at 10 U.S. Geological Survey (USGS) streamflow-gaging stations. Six streamflow-gaging stations included in this study experienced peak streamflows that ranked in the top five for the period of record. Streamflow from the August 2016 flood event exceeded streamflow from the March 2016 flood event for 15 of the 16 USGS streamflow-gaging stations selected in this study.

At least 13 fatalities were reported, and damages resulting from the flood were estimated to be $\$ 10$ billion. In the immediate aftermath of the flood, the USGS and the Federal Emergency Management Agency (FEMA) initiated a cooperative study to evaluate the flood's magnitude, extent, and probability of occurrence. The USGS hydrographers identified and documented 590 high-water marks, some of which were used to create 12 flood-inundation maps that document the extent and depth of flooding. Peak gage-height data, peak streamflow data, and estimated annual exceedance probabilities are provided for 16 streamflow-gaging stations operated by the USGS in Louisiana. 


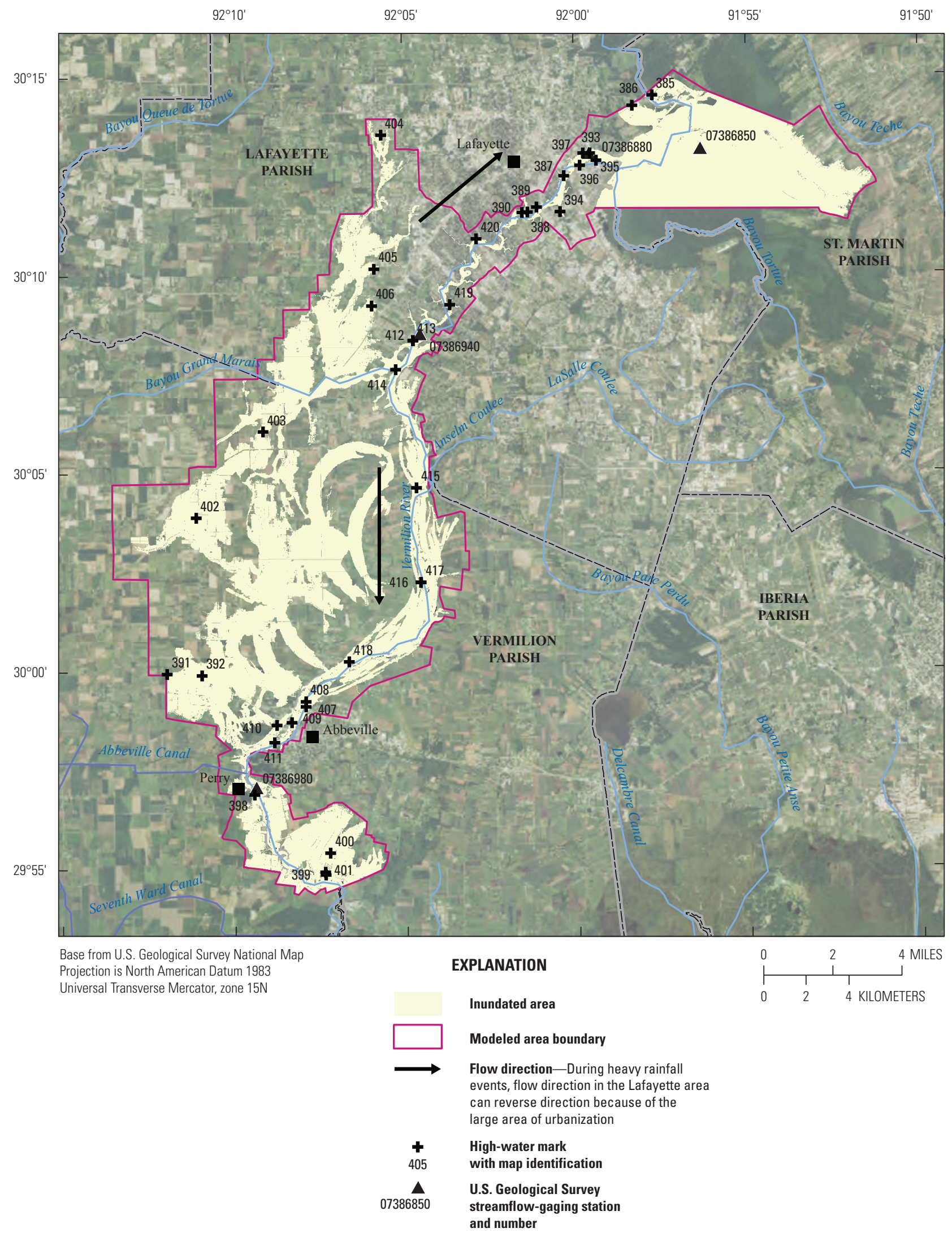

Figure 14. Flood-inundation map of Vermilion River, Louisiana, August 2016. 


\section{Selected References}

Benson, M.A., and Dalrymple, Tate, 1967, General field and office procedures for indirect measurements: U.S. Geological Survey Techniques of Water-Resources Investigations, book 3, chap. Al, 30 p. (Also available at http://pubs.er.usgs.gov/publication/twri03A1.)

Breaker, B.K., Watson, K.M., Ensminger, P.A., Storm, J.B., and Rose, C.E., 2016,Characterization of peak streamflows and flood inundation of selected areas in Louisiana, Texas, Arkansas, and Mississippi from flood of March 2016: U.S. Geological Survey Scientific Investigations Report 20165162, 33 p., accessed November 30, 2016, at https://doi. org/10.3133/sir20165162.

Cohn, T.A., Lane, W.L., and Baier, W.G., 1997, An algorithm for computing moments-based flood quantile estimates when historical flood information is available: Water Resources Research, v. 33, no. 9, p. 2089-2096.

Cohn, T.A., Lane, W.L., and Stedinger, J.R., 2001, Confidence intervals for Expected Moments Algorithm flood quantile estimates: Water Resources Research, v. 37, no. 6, p. 1695-1706.

Durre, Imke, Squires, M.F., Vose, R.S., Arguez, Anthony, Applequist, Scott, and Yin, Xungang, 2012, Computational procedures for the 1981-2010 normals-Precipitation, snowfall, and snow depth: National Climatic Data Center Report, $10 \mathrm{p}$.

Fenneman, N.M., 1946, Physical divisions of the United States: U.S. Geological Survey map, scale 1:7,000,000, 1 sheet.

Heal, E.N., and Watson, K.M., 2017, Flood inundation extent and depth in selected areas of Louisiana in August 2016: U.S. Geological Survey data release, https://doi. org/10.5066/F79K48C1.

Koenig, T.A., Bruce, J.L., O’Connor, J.E., McGee, B.D., Holmes, R.R., Jr., Hollins, Ryan, Forbes, B.T., Kohn, M.S., Schellekens, M.F., Martin, Z.W., and Peppler, M.C., 2016, Identifying and preserving high-water mark data: U.S. Geological Survey Techniques and Methods, book 3, chap. A24, 47 p. (Also available at http://dx.doi.org/10.3133/ tm3A24.)

Louisiana State University, 2016, Atlas Louisiana GIS, accessed October 14, 2016, at http://atlas.lsu.edu/ rasterdown.htm.

Musser, J.W., Watson, K.M., Painter, J.A., and Gotvald, A.J., 2016, Flood-inundation maps of selected areas affected by the flood of October 2015 in central and coastal South Carolina: U.S. Geological Survey Open-File Report 20161019, 81 p. (Also available at http://dx.doi.org/10.3133/ ofr20161019.)
National Oceanic and Atmospheric Administration (NOAA), National Centers for Environmental Information, 2016a, accessed December 8, 2016, at https://www.ncdc.noaa.gov/ billions/events.

National Oceanic and Atmospheric Administration (NOAA), National Weather Service (NWS), 2016b, accessed December 8, 2016, at http://www.weather.gov/lix/ August2016flood.

National Oceanic and Atmospheric Administration (NOAA), 2016c, accessed December 8, 2016, at https://www.climate. gov/news-features/event-tracker/august-2016-extreme-rainand-floods-along-gulf-coast.

National Oceanic and Atmospheric Administration (NOAA), National Centers for Environmental Information, 2016d, accessed December 8, 2016, at https://www.ncdc.noaa.gov/ sotc/national/201608.

National Oceanic and Atmospheric Administration (NOAA), Climatological Data Publications, 2016e, accessed December 19, 2016, at https://www.ncdc.noaa.gov/IPS/cd/ cd.html.

R Core Team, 2016, R: A language and environment for statistical computing: Vienna, Austria, R Foundation for Statistical Computing, accessed December 22, 2016, at https://www.R-project.org/.

Rantz, S.E., and others, 1982a, Measurement and computation of streamflow: U.S. Geological Survey Water-Supply Paper 2175, v. 1, 284 p. (Also available at http://pubs.usgs.gov/ wsp/wsp2175/pdf/WSP2175_vol1a.pdf.)

Rantz, S.E., and others, 1982b, Measurement and computation of streamflow: U.S. Geological Survey Water-Supply Paper 2175, v. 2, 631 p. (Also available at http://pubs.usgs.gov/ wsp/wsp2175/pdf/WSP2175_vol2a.pdf.)

Turnipseed, D.P., and Sauer, V.B., 2010, Discharge measurements at gaging stations: U.S. Geological Survey Techniques and Methods book 3, chap. A8, 87 p. (Also available at http://pubs.usgs.gov/tm/tm3-a8/.)

U.S. Geological Survey, 2016, Short-Term Network Data Portal, accessed October 5, 2016, at http://water.usgs.gov/ floods/FEV.

U.S. Geological Survey, 2017, National Water Information System-Web interface, accessed September 28, 2016, at http://dx.doi.org/10.5066/F7P55KJN.

Veilleux, A.G., Cohn, T.A., Flynn, K.M., Mason, R.R., Jr., and Hummel, P.R., 2014, Estimating magnitude and frequency of floods using the PeakFQ 7.0 program: U.S. Geological Survey Fact Sheet 2013-3108, 2 p. (Also available at http:// pubs.usgs.gov/fs/2013/3108/.) 
Wagner, D.M., Krieger, J.D., and Veilleux, A.G., 2016, Methods for estimating annual exceedance probability discharges for streams in Arkansas, based on data through water year 2013: U.S. Geological Survey Scientific Investigations Report 2016-5081, 136 p. (Also available at http://dx.doi.org/10.3133/sir20165081.)

Wood, S.N., 2004, Stable and efficient multiple smoothing parameter estimation for generalized additive models: Journal of the American Statistical Association, v. 99, p. 673-686.

Wood, S.N., 2011, Fast stable restricted maximum likelihood and marginal likelihood estimation of semiparametric generalized linear models: Journal of the Royal Statistical Society, v. 73, p. 3-36.

Yan, Holly, and Flores, Rosa, 2016, Louisiana flood-Worst US disaster since Hurricane Sandy, Red Cross says:

CNN, accessed December 13, 2016, at http://www.cnn. com/2016/08/18/us/louisiana-flooding/.

For more information about this publication contact:

Director

USGS Lower Mississippi-Gulf Water Science Center

401 Hardin Road

Little Rock, AR 72211

http://ar.water.usgs.gov

Publishing support provided by

Lafayette Publishing Service Center 



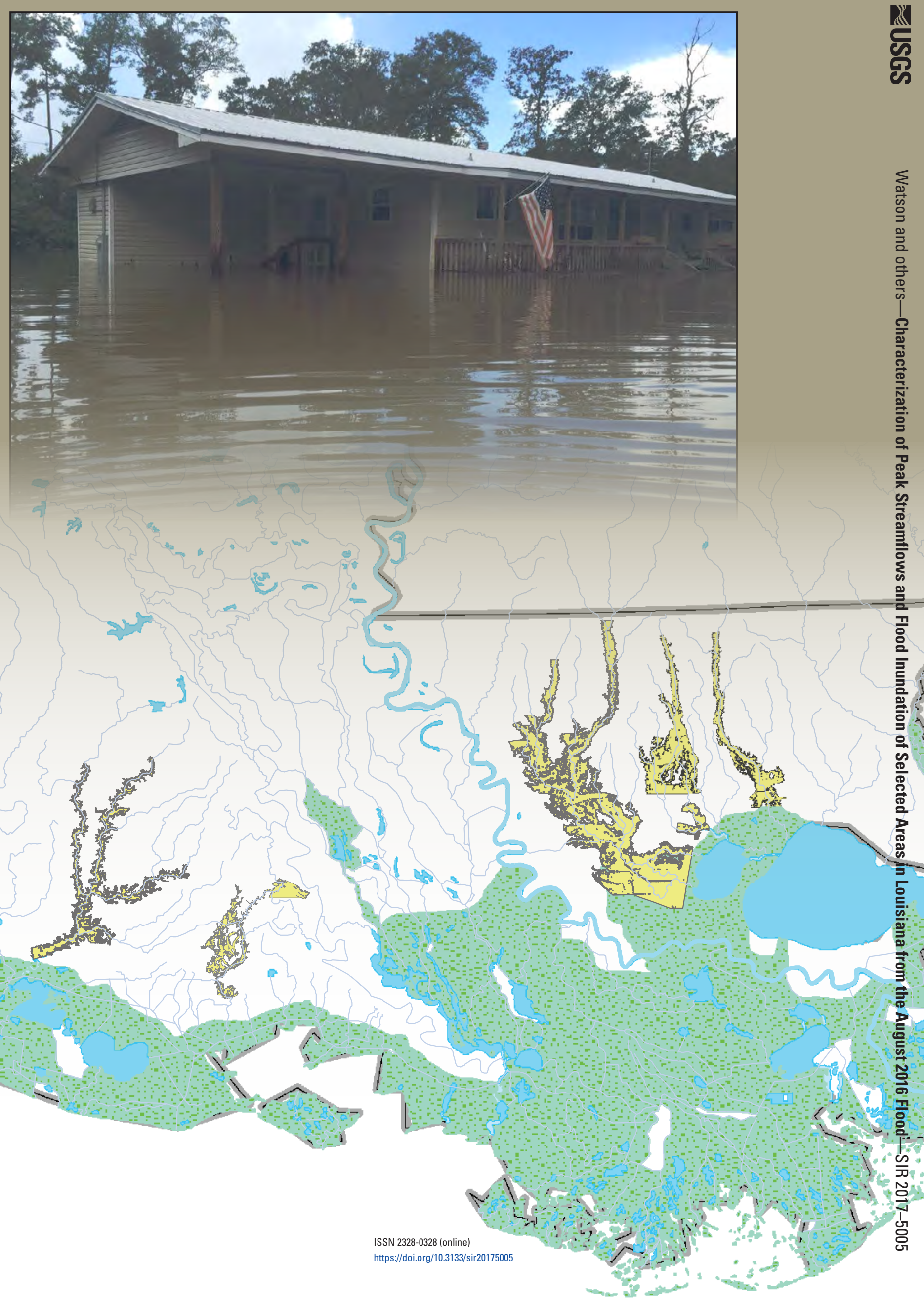

